\title{
SECTIONS 3 AND 9 OF THE INCOME TAX ACT: The Source of InCOMe ConCEPT aNd The "Reasonable Expectation of Profit" Rule
}

\author{
KERRY HARNISH*
}

This article explores the development of several concepts important to the interpretation and application of income tax law in Canada. Specifically, the author traces the evolution of the source of income concept from its conception in the early income tax statutes to its modern usage. The author goes on to describe how this concept underlies the application of ss. 3 and 9 of the present Income Tax Act, and the "reasonable expectation of profit" rule.
L'auteur examine le développement de plusieurs principes essentiels d̀ l'interprétation et $\grave{a}$ l'application de la législation relative à l'impôt sur le revenu au Canada. Il suit notamment lévolution de la notion des sources de revenu - de ses origines dans les premiers textes $\dot{a}$ son usage actuel. Il décrit ensuite comment ce concept soustend l'application des articles 3 et 9 de l'impót sur le revenu, ainsi que la doctrine de l'expectative raisonnable de profit.

\section{TABLE OF CONTENTS}

I. INTRODUCTION ..................... 851

II. THE SOURCE OF INCOME CONCEPT AND RELATED

MATTERS IN THE PRE-1972 INCOME TAX ACTS . . . . . . . . 852

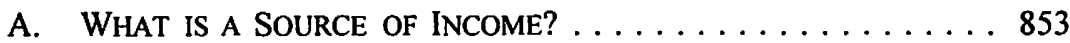

B. COMPUTING INCOME FROM A BUSINESS OR PROPERTY

SOURCE: DISTINGUISHING THE PRE-1948 AND

POST-1947/PRE-1972 APPROACHES . . . . . . . . . . . . . 856

C. THE "CHIEF SOURCE OF INCOME LOSS

CONSTRAINT" RULE . . . . . . . . . . . . . . . . 861

D. THE DEFINITION "PERSONAL OR [AND] LIVING

EXPENSES" AND THE RELIEVING NATURE OF THE

"REASONABLE EXPECTATION OF PROFIT"

TERMINOLOGY USED THEREIN $\ldots \ldots \ldots \ldots \ldots \ldots \ldots 86$

E. THE Evolution of the CASE LAW that

CULMINATED IN THE MOLDOWAN DECISION:

CAN A LOSS BE A SOURCE OF INCOME? AND

DID DICKSON J. MAKE AN ERROR IN

THE MOLDOWAN DECISION? . . . . . . . . . . . . 873

III. SECTIONS 3 AND 9 OF THE ACT AND THE 1996 TONN CASE

APPLYING THE "REASONABLE EXPECTATION OF PROFIT" RULE . . 879

A. SECTIONS 3 AND 9 OF THE ACT $\ldots \ldots \ldots \ldots \ldots \ldots \ldots 80$

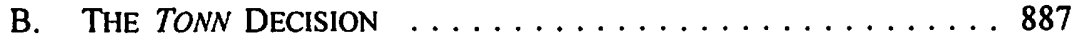

C. POST-TONN COMMENTARY .............. 893

IV. EMERging ISSUE: Convergence of First PrINCIPLES $\ldots \ldots \ldots 897$

B. Comm. (Saint Mary's), LLB/MBA (Dalhousie), of the Department of Finance (Tax Policy Branch/Tax Legislation Division), Ottawa, Ontario. Member of the Barristers' Society of Nova Scotia since 1983. The views expressed in this article are my own, and they do not necessarily represent the official position of the Government of Canada or the Departments of Finance and Justice, or the Canada Customs and Revenue Agency [hereinafter "Revenue Canada"]. 
V. Conclusion ..................... 901

VI. ANNEX: AN ARTICULATION OF THE CASE LAW

CRITERIA APPLICABle IN APPLYING THE OBJECTIVE

"REASONABlE EXPECTATION OF PROFIT" RULE ..........902

\section{INTRODUCTION}

This article seeks to review and comment on the relationship in the Income Tax Act between the source and loss references in ss. 3 and 9, and the role accorded the objective "reasonable expectation of profit" rule. Part II of the article considers how and why the case law evolved to test the existence of a business source of income under the 1952 Act where the business does not earn a profit in a taxation year but, as set out in Moldowan v. M.N.R., ${ }^{2}$ has a reasonable expectation of profit. Detailed consideration is given to particular provisions of the pre-1972 income tax statutes ${ }^{3}$ and related case law, including the source of income concept and the loss constraint rules under the pre-1972 tax law. The failure to relate the wording of the pre-1972 statutes to related cases can thwart a full understanding of the basis for the "reasonable expectation of profit" rule. The analysis in Part II provides that the genesis for the "reasonable expectation of profit" rule is the relationship of the source of income concept to particular statutory rules in place before 1972 (described in detail below) and related case law interpreting those rules. Part III will rely on this analysis for the purpose of considering the wording of ss. 3 and 9 of the post-1971 tax law.

Part III proposes that, from a statutory interpretation perspective, the case is significantly stronger under the present Act for applying an objective "reasonable expectation of profit" rule in determining the existence of a business or property as $a$ source of income. The analysis in Part III focuses on ss. 3 and 9 of the Act. This analysis provides that the most appropriate interpretative approach to identifying the existence of a business or property as a source of income is to determine whether the business or property has a profit in the taxation year under review, or a "reasonable expectation of profit." In the absence of a profit, a business or property loss can be deducted under s. 3 by a taxpayer only if the business or property is a source of income. One should not assume that expense deductions detailed in particular provisions of the Act in respect of a business or property that produces a loss in a taxation year are deductible under paragraph 3(d) of the Act. This article challenges long-held assumptions about ss. 3 and 9 by placing in historical context the wording of these sections. Part III also reviews in this context the 1996 decision of the Federal

I R.S.C. 1985, (5th Supp.) c. I [hereinafter "the Act"]. Unless otherwise stated, statutory references in this article are to the Act. Also see the Income Tax Regulations, C.R.C. 1978, c. 945. Note: References in this article to post-1971 income tax statutes include S.C. 1970-71-72, c. 63 [hereinafter "the 1972 Act"], as am. and replaced by the Act.

2 [1978] I S.C.R. 480; 77 D.T.C. 5213; [1977] C.T.C. 310 (S.C.C.), Dickson J. with Martland, Judson, Spence, and Pigeon JJ. concurring [hereinafter Moldowan].

See the Income War Tax Act, 1917, S.C. 1917, c. 28 [hereinafter "the 1917 Act"]; the Income War Tax Act, R.S.C. 1927, c. 97 [hereinafter "the 1927 Act"]; the Income Tax Act, S.C. 1948, c. 52, as am. [hereinafter "the 1948 Act"]; and the Income Tax Act, R.S.C. 1952, c. 148 [hereinafter "the 1952 Act"]. 
Court of Appeal in Tonn v. M.N.R. ${ }^{4}$ and subsequent commentary on that case and other post-Tonn decisions of the Federal Court of Appeal. Most, if not all, of the leading cases and articles on the "reasonable expectation of profit" rule fail to relate the source reference in the loss rule in subsection $9(2)$ to the profit reference in subsection $9(1)$, the source reference in paragraph 3(a), and the loss offset rule in paragraph 3(d).

Part IV discusses the convergence occurring in the case law of the source of income concept vis-à-vis the deductibility of losses under s. 3 with the principles used to determine the deductibility of expenses for the purpose of computing a statutory income (loss) to which s. 9 applies. The principles concerning the deductibility of expenses are subordinate to the source of income concept, which is a first order principle. Transactions that are not within the ambit of a particular source are not treated the same as those that are within the ambit of the source. The determination of the total net amount of a taxpayer's total worldwide income from sources should begin and end with s. 3. This determination should not begin with whether particular expenses are deductible under a particular provision of the Act. Parliament is responsible for addressing any perceived deficiencies that occur where expenditures or expenses are not deductible because they are incurred in an activity that is not a source of income, or are not incurred within the ambit of a source. Parliament has, for example, enacted s. 20.1 of the Act to permit the deduction of interest expenses incurred in respect of certain properties (and businesses) that cease to be sources of income. Also see moving expenses in s. 62 and child care expenses in s. 63.

In Part V, this article concludes that the "reasonable expectation of profit" rule is a first instance question of law that arises from the wording of all of $s$. 9 read in conjunction with the source of income concept also found in s. 3. This question of law is answered by applying objectively based criteria to particular facts on a case-by-case basis.

Part VI provides an Annex that summarizes the objective criteria that should be considered when determining whether a "reasonable expectation of profit" exists in a particular case.

\section{THE SOURCE OF INCOME CONCEPT AND RELATED MatTerS IN THE PRE-1972 InCOME TAX ACTS}

This Part considers how, when, and why the pre-1972 income tax law evolved to apply an objective "reasonable expectation of profit" rule in determining the existence of a business as a source of income in loss cases. This Part focuses on:

- defining the "source of income" concept;

- reviewing the wording of the income computation rule applicable to business and property sources in the 1927 Act and the 1948 Act (and 1952 Act) with particular 
attention being given to the manner in which each statute addressed the source, profit, and loss concepts (e.g., distinguishing the "profits received by a taxpayer" approach taken to computing income of a business or property under the $1927 \mathrm{Act}$ from "the income from a business or property is the profit therefrom" approach first taken in the 1948 Act (and continued in its successors));

- reviewing the parameters of the special "loss constraint" rules in the pre-1972 statutes;

- articulating the "relieving" nature of the reasonable expectation of profit terminology as used in the 1939 definition "personal and living expenses"; and

- putting in context the evolution of the case law which culminated in the Moldowan decision and reviewing the correctness of that decision. ${ }^{5}$

\section{A. What IS A SOURCE OF INCOME?}

What is a source of income $?^{6}$ In Materials on Canadian Income Tax, $^{7}$ the question is answered as follows:

[T] he source concept of income emphasizes the source from which an amount arises rather than the use to which the amount is put. No income can arise if there is no source. ${ }^{8}$

A source of income should not, therefore, be confused with being a taxpayer. Isaacs $\mathrm{J}$. of the High Court of Australia noted this in stating that a source of income means

not a legal concept, but something which a practical man would regard as a real source of income. Legal concepts must, of course, enter into the question when we have to consider to whom a given source belongs. But the ascertainment of the actual source of a given income is a practical hard matter of fact."

The historic thinking in the case law about the source of income concept has been that a source of income refers to productive activity that results in accretions to a taxpayer's wealth because of:

\section{Supra note 2.}

For a different perspective, see C. Fien, "To Profit or Not To Profit: A Historical Review and Critical Analysis of the 'Reasonable Expectation of Profit' Test" (1995) 43 Can. Tax J. 1287. Fien provides a historical review of the reasonable expectation of profit test and comments on the reasonable expectation of profit rule, including the underlying source of income concept in s. 3 of the pre-1972 tax law. Fien's comments on the "source of income" concept are at 1295-1301.

7 W. Grover \& F. lacobucci, eds., Materials on Canadian Income Tax, 4th ed. (Toronto: Richard De Boo Limited, 1980).

* Ibid. at 148.

" Nathan v. Federal Commissioner of Taxation (1918), 25 C.L.R. 183 (H.C. Aus.) at 189-90; adopted in M.N.R. v. Robertson, 54 D.T.C 1062 at 1068; [1954] C.T.C. 110 at pages 120-22 (Ex. Ct.) [hereinafter Robertson]. 
periodic payments for services rendered to an employer (where employment is the source) or for business activity (where the business is the source) or for the use of property (where the property is the source). ${ }^{10}$

Thus the source of income question is a two-step enquiry. The first step is the nittygritty task of culling through the facts and ascertaining the actual source of income, if any. Once done, the income (loss) is that of a taxpayer, as provided for in law. Under this two-step approach, a taxpayer's subjective intention is not conclusive of the existence or non-existence of any particular source of income. Rather, subjective intent is but one important factor that must be considered for the purpose of ascertaining the source of the income.

The source of income concept can arise in at least two income tax contexts. First, the source of income concept applies to determine whether an amount is to be added to a taxpayer's income because of the application of the "non-enumerated source of income" rule in s. 3 of the 1952 Act and paragraph 3(a) of the Act. This s. 3 residual source rule ensures the inclusion into income of income from sources not identified in the Act." What a practical man may regard as a source of income on the facts is not necessarily the same as what an affected taxpayer, tax professional, or Revenue Canada may consider to be a source of income, although the views of those affected parties are important considerations for the judiciary. Where a taxpayer's amount is not from a source of income, it is not, in the absence of a specific rule, income to which $\mathrm{s}$. 3 applies. A source of income has been noted not to include, for example, "gifts, inheritances and windfalls," ${ }^{12}$ strike pay, ${ }^{13}$ or capital gains ${ }^{14}$ (which have since been included in the income base ${ }^{15}$ ). However, the residual source rule can apply to receipts having the character of income; for example, to casual receipts arising from an isolated

P. Hogg \& J.E. Magee, Principles of Canadian Income Tax Law, 2d ed. (Toronto: Carswell, 1997) at part 9-2.

" Non-enumerated sources of income (the s. 3 residual) should be distinguished from identified sources of income including those listed only in subdivision $d$ of Part I to the Act (i.e., "Other Sources of Income"). See Schwartz v. M.N.R., [1996] I S.C.R. 254, 96 D.T.C. 6103; [1996] 1 C.T.C. 303 (S.C.C.). The majority opinion of La Forest J. (L'Heureux-Dube, Gonthier and McLachlin JJ. concurring) found that s. 3(a) applies to non-enumerated sources. However, s. 3(a) did not apply in that case. This was because the more general s. 3 residual source rule could not be given preference to the more detailed definitions "retiring allowance" and "employment" in $\mathbf{s .}$ 248 (1) of the Act that applied to the other source of income in s. 56 called "retiring allowances," and which did not apply. The minority opinion of Major J. (Sopinka and lacobucci JJ. concurring) agreed with the general findings but indicated the court should not have decided the nonenumerated source issue. Note: application of the "employment" source of income rules was not at issue in the matter before the Supreme Court. For detailed commentary on the Schwartz case, see K. Harnish, "Interpreting the Income Tax Act: Purpose v. Plain Meaning and the Effect of Uncertainty in the Tax Law" 35 Alta. L. Rev. 687 at 705-23.

12 Grover \& lacobucci, supra note 7 at 149.

13 Fries v. M.N.R., [1990] 2 S.C.R. 1322; 90 D.T.C. 6662; [1990] 2 C.T.C. 439 (Sopinka J. for the court; Lamer C.J., and Wilson, La Forest, L'Heureux-Dube, Sopinka, Gonthier, Cory, and McLachlin JJ.).

i4 Supra note 7 at 149.

is See paragraph 3(b) and subdivision $\mathrm{c}$ to Part I of the Act, which has included taxable capital gains in the income base since 1971. 
act or exceptional transaction notwithstanding that such receipts do not have the character of income from an employment, office, business, or property (or from an "other source" listed in subdivision $d$ to Part $I$ of the Act). ${ }^{16}$ Also, casual receipts could be in respect of "an adventure or concern in the nature of trade," which is within the meaning of the definition "business" in s. 248(1) of the Act.

Second, the source of income concept arises in the context of whether a taxpayer has income from one of the following productive sources listed in s. 3 of the 1952 Act and the Act: an "office, employment, business or property." For a business or property, the existence of a business or property as a source of income goes beyond whether the inclusive definition "business" or the exhaustive definition "property" is satisfied in the present or past income tax statutes. ${ }^{17}$ For example, a taxpayer's business is a source of income in a taxation year only if it has a profit or a reasonable expectation of profit $^{18}$ in the year (and determining why this is appropriate under the tax law is the main objective of this article). However, a gain from the disposition of property is a taxable capital gain to which the special inclusion rule in paragraph 3(b) of the Act applies regardless of whether the property is held by a taxpayer in respect of a property or business source of income. Of course, capital gains were not subject to taxation under the $1917,1927,1948$, or the 1952 Acts.

There are at least three critical things that must be considered in the context of relating the source of income concept and the reasonable expectation of profit rule. Each will be considered separately after being summarized. First, the pre-1948 income

In 1951, a lawyer's guarantee of a bank loan was found to be a source of income even if it was not a business source. See Steer v. M.N.R., 65 D.T.C. 5115 (Ex. Ct.) [hereinafter Steer]. In Steer, the taxpayer incurred a loss on the guarantee which was used to offset income from other sources. (Losses from non-enumerated source cannot be deducted under paragraph 3(d) of the current Act.) For commentary on Steer, see J. Ellis, "Aggregation of Income and Losses from Various Sources" in B. Hansen, V. Krishna \& J. Rendall, eds., Canadian Taxation (Toronto: Richard De Boo, 1981) 443 at 445 . Also, a 1930 treatise on Canadian income tax law indicates that the Crown in Great Britain relied on the non-enumerated source rule in the then British income tax legislation for tax receipts from isolated or exceptional transactions; namely, commissions received by two directors for guaranteeing a corporation's bank overdraft, commissions received by a taxpayer from a syndicate for underwriting shares of a new company, and taxpayer profits from speculating in future contracts. See C.P. Plaxton \& F.P. Varcoe, Dominion Income Tax Law, 2d ed. (Toronto: Carswell, 1930) at 137-38. The cases cited are Ryall v. Hoare (1923), 8 Tax Cas. 521 (commissions received by two directors for guaranteeing a corporate overdraft); Cooper v. Stubbs (1925), 10 Tax Cas. 29 (profits from speculating in cotton futures); and Lyons v. Cowcher (1926), 10 Tax Cas. 438 (commissions received for underwriting a share issue). That treatise also directs the reader to Morrison v. M.N.R., [1928] Ex. C.R. 75; 1920-1940 D.T.C. 113, which considered the non-enumerated source rule in s. 3 of the 1917 Act, rejected the doctrine of ejusden generis when interpreting s. 3 , and concluded the taxpayer's activity was a business source of income. For these definitions, see s. 127 of the 1948 Act; s. 139 of the 1952 Act; and s. 248(1) of the Act. In Global Communications v. M.N.R., 99 D.T.C. 5377 (F.C.A.) [hereinafter Global Communications], Mr. Justice Robertson (Strayer and DéCary JJ.A concurring) stated at 5384 that:

The definition of "business" set out in subsection 248(1) of the Income Tax Act is not helpful in identifying what constitutes a business. According to the jurisprudence, a business is best described as an organized activity carried on with a view to a reasonable expectation of profit. 
tax statutes took a "profits received by a taxpayer" approach to business and property profits rather than "the profit therefrom" approach taken in the basic business and property income computation rule in the post-1947 statutes. This matter is considered in section $\mathrm{B}$ below and Part III.

Second, the statutory approach taken to the source of income and loss concepts differs in the post-1947/pre-1972 statutes from the approach taken in the post-1971 statutes. This will be considered in both this Part and Part III, which analyzes ss. 3 and 9 of the Act.

Third, many of the early loss cases concern farm losses in which the source of income concept is not fully considered. Focusing on such cases can muddle the source of income concept as enacted in the present Act unless those cases are considered in the context of the special rules that historically applied to constrain the deductibility of losses, including farm losses. This matter is taken up in sections $\mathrm{C}$ to $\mathrm{E}$ below.

\section{B. Computing Income From a Business or Property SOURCE: Distinguishing THE PRE-1948 AND POST-1947/PRE-1972 APPROACHES}

Caution should be exercised when considering the "reasonable expectation of profit" rule and the pre-1948 and post-1947/pre-1972 income tax statutes and related cases. This is because of key statutory differences in the approaches taken to computing a taxpayer's income (loss) from a business or property. The best way to explain these differences is by reference to particular rules.

\section{THE APPROACH TAKEN TO COMPUTING INCOME IN THE 1927 ACT (AND THE 1917 ACT)}

Section 3 of the 1927 Act stated, before the enactment of the 1948 Act, the following:

3. For the purposes of this Act, "income" means the annual net profit or gain or gratuity, whether ascertained and capable of computation as being wages, salary, or other fixed amount, or unascertained as being fees or emoluments [i.e., profit from an employment or office or labour], or as being profits from a trade or commercial or financial or other business or calling, directly or indirectly received by a person from any office or employment, or from any profession or calling, or from any trade, manufacture or business, as the case may be whether derived from sources within Canada or elsewhere; and shall include the interest, dividends or profits directly or indirectly received from money at interest upon any security or without security, or from stocks, or from any other investment, and, whether such gains or profits are divided or distributed or not, and also the annual profit or gain from any other source including.... ${ }^{19}$

At least three things should be noted about this provision. First, s. 3 of the 1927 Act is analogous to s. 3(1) of the 1917 Act and both provisions use the phrase "received by a person" in the context of computing profit from the person's employment, business 
or investment source of income. A strict and literal reading of s. 3 required a taxpayer to take a cash-basis approach to income for the purpose of determining the amount of business profits received into income by the taxpayer in a taxation year. That is to say, an accrual approach could not be used to compute the amount of business or property profits received by a taxpayer. Yet this cash-basis requirement was not generally perceived until settled by the 1946 Exchequer Court decision in Trapp v. M.N.R. ${ }^{20}$ The following was stated at the time in the Carswell Editorial Comment accompanying the Trapp decision:

It is rarely that a judgment appears in any field of law which, if followed to the letter, would reverse twenty-nine years of business and governmental practice. The conclusions and the reasons for judgement in this case will have just such a far-reaching and revolutionary effect upon tax practice and business thinking if they are adhered to by the authorities. ${ }^{21}$

It is more than coincidental that the 1927 Act was shortly thereafter replaced by the 1948 Act. $^{22}$

Second, the words "profit" and "gain" connote a net concept, as indicated by the following:

[I]ncome profit or gain has been decisively established ... to mean the receipts from the trade after the deduction of all expenditures incurred in earning them. It is thus apparent that income profit or gain ... is commonly referred to as net income. ${ }^{23}$

1941-1946 D.T.C. 784; [1946] C.T.C. 30 (Ex. Ct.) [hereinafter Trapp, cited to C.T.C].

21 Ibid. at 31 . As late as 1939 , the following was thought to be the law with respect to the use of the word "received" in s. 3 of the 1927 Act:

The use of the word "received" suggests that profits "accrued" or "earned" but not actually received are not within the scope of the definition of income. It does not, however, follow that income is confined to that which the taxpayer actually receives. For instance, where income tax is deducted at the source the taxpayer never receives the sum deducted but it accrues to him. Moreover, as is well known, the annual profits or gains of a trader or commercial company are not properly measured by considering only the moneys taken in. In preparing a balance sheet and profit and loss account, the trader does not confine himself to actual receipts, does not prepare a mere cash account, but values his book debts and his stock-in-trade and so on and calculates his profits accordingly. From the practice of commerce and as accountants and from the necessity of the case, this is so. In such cases, income must include accrued income as a matter of practical necessity.

H.A.W. Plaxton, Canadian Income Tax Law (Toronto: Carswell, 1939) at 31 [footnotes omitted]. Supra note 3. See "Data Paper: Business Income and Taxable Income" (Report of Proceedings of the Seventh Annual Tax Conference, Winnipeg, 23-24 November 1953) (Toronto: Canadian Tax Foundation, 1954), 1-35 of Appendix A, especially at 1-8.

F.E. LaBrie \& J.R. Westlake, Deductions Under The Income War Tax Act: A Return to Business Principles (Toronto: University of Toronto Press, 1948) at 1-2; see especially note 5 accompanying that publication [emphasis in original, footnotes omitted]. The question of whether an expenditure was deductible given then paragraph 6(a), which required it be made wholly, exclusively, and necessarily for the purpose of earning income, depended upon application of the "income-earning process concept." See $i b i d$. at $41-49$. 
Third, while s. 3 of the 1927 Act refers to the source concept, it does not mention the loss concept. Business losses sustained in a taxation year could not be deducted from income of the business in another year ${ }^{24}$ unless expressly permitted by the statute. By 1942, paragraph 5(1)(p) of the 1927 Act was added to provide expressly a carryover deduction of certain business losses (incurred in another taxation year) from business income earned in a current taxation year. ${ }^{25}$ As for losses sustained in a current taxation year, Herbert Plaxton was of the view in 1939 that:

Since the general scheme of the [1927] Act requires that the net profit or gain of the taxpayer from whatever source derived is to be determined, the losses sustained in connection with one business, trade, calling or occupation should be deductible from the profits or gains derived from another business, trade, calling or occupation by the taxpayer. ${ }^{26}$

Query whether a business loss could be "received" by a taxpayer? Regardless, $s .10$ of the 1927 Act provided a loss constraint rule that precluded a taxpayer's income from being less than the income derived by the taxpayer from the taxpayer's "chief position, occupation, trade, business or calling." That rule, and the analogous rule in s. 13 of the 1948 Act and the 1952 Act, is considered in detail after first reviewing the approach taken in the 1948 Act and the 1952 Act to computing a taxpayer's s. 3 income.

\section{THE APPROACH TAKEN to COMPUTING INCOME IN THE 1948 ACT AND THE 1952 ACT}

The general income computation rule in s. 3 of the 1952 Act, first enacted with the 1948 Act, stated before 1972 that:

3. The income of a taxpayer for a taxation year for the purposes of this Part is his income for the year from all sources inside or outside Canada and, without restricting the generality of the foregoing, includes income for the year from all
(a) businesses,
(b) property, and
(c) offices and employments. 27

At least four things should be noted about this provision. First, the provision does not include the phrase "received by a person." Second, and consistent with point one, the provision does not indicate the manner in which a taxpayer is to compute income from sources.

See Plaxton, supra note 21 at 99-100. The cases referenced are: Broughton and Plas Power and Coal v. Kirkpatrick (1884), 14 Q.B.D. 491 at 496, Grove J.; Collness Iron v. Black (1881), 6 A.C. 315 at 327, Blackburn J.; and Union Natural Gas v. Dover (Township) (1920), 53 D.L.R. 326 at 328, Anglin J.

27 See the 1952 Act and the 1948 Act, supra note 3 [emphasis added]. 
Third, the reference to income's being a taxpayer's income "from all sources" was said in James v. M.N.R. ${ }^{28}$ to have "abrogated the view that there must be income in the sense of profit to be a source of income within the meaning of the [1948/1952] Act."29 Regardless of whether this suggestion is correct, the 1973 James decision suggests, at a minimum, two types of uncertainty with respect to s. 3 of the 1948 Act and the 1952 Act. It was unclear whether s. 3 of those statutes merged (or blurred) separate sources of income of a taxpayer into one overall income amount per taxpayer. It was also unclear whether the then wording of s. 3 abrogated the need to have a profit to be a source of income under the 1952 Act.

Fourth, s. 3 of the 1948 Act and 1952 Act does not mention the business or property profit or loss concepts. However, with respect to profits of a business or property, the basic business and property income computation rule in s. 4 of the 1952 Act, first enacted with the 1948 Act, stated before 1972 that:

4. Subject to the other provisions of this Part, income for a taxation year from a business or property is the profit therefrom for the year. ${ }^{30}$

Two things should be noted about this wording. First, s. 4 of the 1948 Act was the first Canadian income tax provision to use "the profit therefrom" terminology in the context of computing business or property profit produced by the particular business or property. ${ }^{31}$ The profit is not only from a taxpayer's business or property (and belongs to the taxpayer) but s. 4 sets down an objective standard for measuring profit. ${ }^{32}$ This objective standard relies on "well-accepted principles of good business practice and judge-made law," 33 both of which are (or can be made) subject to the statute. One Canadian tax jurist stated the following about the terminology:

[T]he basic definition of a taxpayer's income for a taxation year from a business as "his profit therefrom for the year" may, depending on the circumstances, raise a question:

28 73 D.T.C. 5333; [1973] C.T.C. 457 (F.C.T.D.) [hereinafter James].

$29 \quad$ Ibid. (D.T.C. at 5336; C.T.C. at 462).

3. Supra note 3 [emphasis added].

"The enacted "is the profit therefrom" phrase replaced the initial draft proposed in 1947 that called for a determination of income from a business or property "in accordance with generally accepted accounting principles." For a discussion of why the change was made, see the "Data Paper: Business Income and Taxable Income," supra note 22 at 1-8. Also see LaBric \& Westlake, supra note 23 at $112-15$. It should also be noted that the phrase "is the profit therefrom" differs from the "for profit" test first used in paragraph 3(1)(f) of the 1917 Act (infra note 38) and subsequently used post-1947 in the definition "personal or living expenses."

$32 \quad$ Note also that the 1948 Act did not negate deductions from income merely because they were not "wholly, exclusively and necessarily" expended for the purpose of earning income, as was the case with paragraph 6(a) of the 1927 Act. Among other things, the omission of that terminology from the 1948 Act may have removed a second impediment to computing s. 4 profit on an accrual basis rather than cash basis. See LaBrie \& Westlake, supra note 23 at 110.

") See the Supreme Court decisions in Canderel, infra note 111, and Symes v. M.N.R., [1993] 4 S.C.R. 695; 94 D.T.C. 6001; [1994] I C.T.C. 40 (S.C.C.), S.C.R at 723-24; D.T.C. at 6009-10; C.T.C. at 51-52, lacobucci J. Also see Royal Trust Company v. M.N.R., 57 D.T.C. 1055 at 1061; [1957] C.T.C. 32 at 43 (Ex. Ct.), Thorson P. [hereinafter Royal Trust]. 
(a) as to whether a transaction falls within the ambit of the business,

(b) as to whether a transaction was a revenue transaction or a capital or some other kind of transaction,

(c) as to which transactions should be allocated to the year, or

(d) as to how, having regard to all the operating transactions falling within the ambit of the business that are allocated to the particular taxation year, "profit" from the business for that taxation year should be computed.

At this point, it is worth commenting that there is much jurisprudence with reference to these various classes of problem and that, frequently, the reasoning or "principle" adopted by the Courts to solve a particular class of problem has tended to develop into a rule of law."

It should not be surprising, therefore, to learn that the judiciary would eventually develop, rely on, and apply an objectively-based "reasonable expectation of profit" rule for the purpose of determining whether a business or property loss is, based on the evidence, from a business or property source of income.

The second thing to note about the above referred to s. 4 is that, while it refers to the business and property profit concept, it fails to refer to the source of income concept and the loss concept. A loss was defined under the post-1947/pre-1972 statutes as follows:

139(1)(x). "Loss" means a loss computed by applying the provisions of this Act respecting computation of income from a business mutatis mulandis (but not including in the computation a dividend or part of a dividend the amount whereof would be deductible under $\mathrm{s}$. 28 or subsection (6) of section $68 \mathrm{~A}$ in computing taxable income) minus any amount by which a loss operated to reduce the taxpayer's income from other sources for the purpose of income tax for the year in which it was sustained. ${ }^{35}$

This loss definition highlights two significant points about the source of income concept and the former statutory relationship existing between a taxpayer's loss and the taxpayer's world-wide income. First, no mention is made in the definition as to the necessity of a loss being from a business source of income (or from a property, office, or employment source). The wording of the relevant provisions in the 1948 Act and the 1952 Act provided only that a loss was to be computed by applying the provisions respecting the computation of income from a business and the loss carryover rules apply to business losses only. The wording assumes that a loss computed by a taxpayer is from a business source of income of the taxpayer. It does not address the possibility that the loss may be, for example, from a property source of income (or a hobby for Conference 1981) (Toronto: Canadian Tax Foundation, 1982), 285 at 287-88 [emphasis added]. 
that matter). The relevance of this deficiency should not be underestimated although the extent of its importance is unclear. ${ }^{36}$

Second, significant ambiguity existed in determining how this definition of "loss" applied in the context of the income "from all sources" rule in s. 3 of the 1948 Act and the 1952 Act. Thus, not only was there uncertainty as to the types of activity to which the loss definition applied, it took the Supreme Court of Canada to determine that a taxpayer could deduct a business loss incurred in a taxation year against income produced by another source in the year, and that the loss had to be applied against that other income first before being deductible from the taxpayer's income in another taxation year. ${ }^{37}$

Moreover, Parliament had on-going concerns about the deductibility of losses. These concerns manifested into two main types of rules, one of which related to the source of income concept and the other to the non-deductibility of expenses otherwise deductible in computing income from a source. Section $C$ below reviews the chief source of income concept, which in one form or another has constrained loss offsets since 1919. Section D below reviews personal and living expenses, the meaning of which eventually evolved into an extended definition that continues to make nondeductible certain otherwise deductible expenses incurred to maintain property.

\section{THE "Chief Source of Income Loss ConstrainT" Rule}

Early on in the life of Canadian income tax law, Parliament mandated income computations that constrained the deductibility of losses arising from secondary sources of income. Paragraph 3(1)(f) of the 1917 Act provided:

(f) deficits or losses sustained in transactions entered into for profit but not connected with the chief business, trade, profession or occupation of the taxpayer shall not be deducted from income derived

36 For example, see Steer, supra note 16, which concerned a loss incurred on a guarantec. One question raised by this deficiency in the pre-1972 definition of loss is specifically noted in F.E. LaBrie, The Principles of Canadian Income Taxation (Don Mills: CCH Canadian Ltd., 1965). At pages 157 and 158, that text asks whether a capital cost allowance deduction made in respect of property and which reduces income "from the property" to a negative or loss amount means the loss can be applied against other sources of income. The following is stated in reply at page 158:

In part, the answer depends on sec. 3 and whether in stating that the taxpayer's income for a taxation year is his income from the year from all sources the section envisages a mere totalling of separate computations from each source or an overall aggregate computation covering all sources. Section 13, which places a limitation on what would appear to be otherwise a deductibility of losses incurred in farming would appear to indicate that the latter is what is meant. Section $139(1)(x)$, which defines "loss" to mean ... also implies that losses from any source are simply absorbed in a computation of the "taxpayer's income for the year from all sources." [Emphasis added.]

Query whether the definition "personal or living expenses" in s. 248(1) of the Act would preclude this result if the property were not maintained in respect of a business, etc.? See the analysis in section D of this Part, which concerns that definition.

17 See Wahn v. M.N.R., [1969] I S.C.R. 404, 69 D.T.C. 5075; [1969] C.T.C. 61 (S.C.C.). Also see the commentary of Ellis, supra note 16 at 444-46. For commentary on the 1923 change that replaced the "for profit" test, see Ellis, supra note 16 at $446-49$. 
from the chicf business, trade, profession or occupation of the taxpayer in determining his taxable income. ${ }^{38}$

However, this "losses sustained in transactions entered into for profit but not connected with the chief business" approach was soon revised. Section 10 of the 1927 Act deemed a taxpayer's income for a taxation year to be equal to no less than the amount of the taxpayer's income from the taxpayer's "chief position, occupation, trade, business or calling." The Minister of National Revenue also had the discretion to determine which one or more sources were a taxpayer's chief position, occupation, business, or calling.

The enactment of the 1948 Act brought with it a further refinement of the chief position rule constraining loss offsets. In particular, the income of a taxpayer was deemed by s. 13 of the 1948 Act to be no less than the amount of the taxpayer's "chief source of income," and the Minister of National Revenue could determine which source or sources combined was a taxpayer's chief source of income.

Six points are worthy of note with respect to these loss constraint rules. First, the 1917 loss constraint rule concerned a taxpayer's losses from secondary sources carried on for profit and not connected to the taxpayer's chief business, etc. Arguably, this approach looked to a taxpayer's subjective intent to determine if secondary transactions were engaged in for profit.

Second, neither the transactions entered into for profit rule in the 1917 Act nor the chief position rule in the 1927 Act constrained the deductibility of losses against investment (property) sources of income. This was because investment sources of income were not within the substance of the "chief business, trade, profession or occupation" test in paragraph 3(f) of the 1917 Act and the "chief position, occupation, trade, business or calling" rule in s. 10 of the 1927 Act. ${ }^{39}$ The effect of the Hatch decision was that a taxpayer's income from an investment (property) could be fully offset by a loss (from a source) regardless of whether the taxpayer's investment was a separate source(s) or the taxpayer's chief source of income. ${ }^{40}$ The Hatch case is also

S.C. 1919 , c. 55 , s. $2(2)$, as am. by S.C. 1920 , c. 49 , s. 2 , and S.C. 1923 , c. 52 , s. 1 [emphasis added].

19 See Halch v. M.N.R, 1920-1940 D.T.C. 447; [1938-39] C.T.C. 85 (Ex. Ct.) [hereinafter Hatch]. In Hatch, the taxpayer owned a personal corporation that held investments and, in 1927, the corporation acquired a horse breeding and stables operation. The corporation offset the investment profits with losses incurred in the corporation's farm operation, with the net amount being deemed income of sharcholder Hatch (s. 21 of the 1927 Act deemed a personal corporation's profits to be distributed to its shareholders on the last day of the corporation's fiscal period). The Crown argued that the personal corporation had income from two sources, farming and investments, and that the chief position rule in s. 10 applied to preclude the farm loss offset. The Exchequer Court found that the corporation's farm operation was a business carried on for profit and that the investments were not a separate business per se. The corporation had but one source of income, which was farming. However, the decision also highlighted the fact that the chief position, occupation, business, or calling rule did not refer to property sources per se.

40 Ibid. This is one implication of the decision. It should be noted, however, that the narrow ratio of the case could be that a "personal corporation" was not a taxpayer under the then wording of the 1927 Act (i.e., it could not have a "chief position" to which s. 10 could apply). Nevertheless, the 
considered in section D below, which concerns the definition "personal and living expenses," with the Hatch decision providing one of the reasons for enacting that definition.

Third, the "chief source of income" rule in the 1948 Act partially constrained loss offsets against investment (property) sources of income. This was because s. 13 of the 1948 Act employed a chief source of income test that brought investment (property) sources of income within the ambit of the rule thereby restricting otherwise allowable loss offsets against a taxpayer's chief source of income. ${ }^{41}$ This change partially reversed Hatch-like cases; partially in the sense that a loss from a secondary source could reduce a taxpayer's income from a secondary source but could not reduce income from a chief source of income, including a chief source that was an investment (property) source.

Fourth, distinguishing among sources of income was necessary in the context of determining a taxpayer's chief source of income under the 1948 Act and the 1952 Act, notwithstanding previously mentioned dicta in the 1973 James $^{42}$ case. That dicta suggests that the income is a taxpayer's income from all sources approach taken in $\mathrm{S}$. 3 of the 1952 Act (and the 1948 Act) blurred or muddled the separate source approach to computing income. Regardless of whether this is correct, the chief source of income loss constraint rule required that a separate source approach be taken for the purpose of determining which source (or sources combined) was a taxpayer's chief source of income for the purpose of constraining loss offsets. It is quite possible, therefore, that a source of income existed under s. 13 of the 1948 Act and the 1952 Act only if a profit had been produced. Eventually, the judiciary would be called upon to decide this matter.

Fifth, farm losses were not expressly dealt with in any of the above noted 1917, 1927 , and 1948 approaches to constraining the deductibility of losses from secondary sources. This is important because in the early case law the Crown was not relying on special rules that applied exclusively to farm losses. Rather, the source issue was often assumed in the taxpayer's favour with disputes centring on whether more general restrictions on deductibility applied to a source of income. Yet prior to the $1948 \mathrm{Act}$, Revenue Canada had an administrative policy under which the maximum amount of farm losses incurred in a year that could offset a secondary source of income for the

following was stated in 1952 about the matter:

Section 10 of the Income War Tax Act became section 13 of the new Act with an important change in principle. The expression "chief source of income" was substituted for chief position, occupation, etc., thereby permitting the government to assert that the management of investments and the receipt of income therefrom could be a chief source not subject to the deduction of losses in a secondary business activity.

See S. Thom, "1952 Tax Highlights" (Report of Proceedings of the Sixth Annual Tax Conference, Montreal, 3-4 November 1952) (Toronto: Canadian Tax Foundation, 1953) at 17. 
year was limited to no more than one-half of the farm loss. ${ }^{43}$ This practice was overturned in 1952 by the Exchequer Court decision in National Trust Company (Executor for Robert Ray McLaughlin) v. M.N.R. ${ }^{44}$ In particular, Thorson P. stated:

If they [personal and living expenses] were [deducted] their deduction from his other income was prohibited by Section 6(f). But if they were not, there was no reason why their deduction should not be allowed, in which case the appeals must be allowed.

It follows from what I have said that if the expenses were personal and living expenses within the meaning of the section the Minister had no right to allow $50 \%$ of them as a deduction and his action in doing so was contrary to the Act. ${ }^{\text {ts }}$

However, Parliament amended the tax law in 1951 to limit, retroactively to 1949 and subsequent taxation years, the deductibility of farm losses of a taxpayer whose chief source of income was not from farming or a combination of farming and some other source. $^{46}$ A taxpayer's total income as otherwise determined from all sources could

This policy was referred to in No. 42 v. M.N.R., 52 D.T.C. 56, at 56-57; (1952), 5 Tax A.B.C. 382 at 383 (T.A.B.), in which the following was stated:

[The taxpayer] was advised that gentlemen farmers who had other occupations and who were residing on their farms were permitted by the Department to deduct fifty per cent of their farm losses. It was only after the Minister assessed him, disallowing the deduction in respect of his farm loss, that he learned that the deduction of fifty per cent of farm losses had been allowed only where the taxpayer had sufficient investment income to absorb the fifty per cent of the loss claimed as a deduction, and that these other taxpayers had not been permitted to deduct any of their farm losses from the income from their chief occupation.

Revenue Canada attempted to withdrawn from this policy with the enactment of the 1948 Act. The following was stated in 1952:

Under the old Act a truce had been reached [between Revenue Canada and gentleman farmers] whereby 50 percent of such losses could be deducted from secondary income. I understand that after the introduction of the new Act the government attempted to withdraw from this practice, which no doubt generated the pressure required to bring about the amendment of 1951 [retroactive to 1949 and subsequent taxation years (see infra note 47)]. See Thom, supra note 40 at 17. Also see Ellis, supra note 16 at $446-49$ and D.K. McNair, G.H. Munro \& K. Oelschlagel, Taxation of Farmers and Fishermen, looseleaf (Scarborough: Carswell, 1999) at 5:12.

52 D.T.C. 1159; [1952] C.T.C. 264 (Ex. Ct.) [hereinafter McLaughlin Estate].

45 Ibid. (D.T.C. at 1160; C.T.C. at 266). Also see infra note 46.

4. After Revenue Canada tried to withdraw from its pre-1949 administrative practice of permitting the deduction of 50 percent of a part-time farmer's farm loss, affected farmers sought confirmation of Revenue Canada's administrative policy (these requests would have occurred before the 1952 result in McLaughlin Estate, supra note 44, which favoured taxpayers). The codification of the administrative practice was constraining (in two respects) and relieving (in two respects):

- Constraining in the following two respects. First, it reflected the then government's resolve to constrain the deductibility of farm losses, which were by 1949 already constrained in the context of their deductibility from a taxpayer's chief source of income, as enacted in the 1948 Act. The government had no legislative authority for its practice of denying gentlemen farmers 50 percent of their farm losses to offset income from secondary sources (see supra notes 43 and 44). By legislating the practice, the government ensured farm loss restrictions would apply regardless of the outcome in the McLaughlin Estate case (supra note 44). Second, the change was constraining in the sense that the 1951 enactment expressly allowing for 50 percent deductibility capped the deduction at $\$ 5,000$ a year. 
be offset by no more than the lesser of $\$ 5,000$ and one-half the farm loss, which is the initial formulation of the restricted farm loss rule. ${ }^{47}$

Sixth, Parliament repealed in 1952 the "chief source of income loss constraint" rule but kept the then recently enacted "restricted farm loss" rule. ${ }^{48}$ This change reversed Parliament's historic position with respect to the extent to which losses could reduce a taxpayer's income and, of course, income tax payable. Nevertheless, the then Minister of Finance, the Honourable Douglas Abbott framed the matter in terms of farm losses of gentlemen farmers. In particular, Mr. Abbott stated the following in reply to two questions posed in the House of Commons and failed to reply to a question posed by Mr. Knowles:

[Minister Abbot in reply to Mr. Fleming] The idea of the provision [the restricted farm loss rule in subsection 13(1), which was in subsection 13(3) when added in 1951] was to limit the deduction which a gentleman farmer may take for income tax purposes against other income as a result of farm losses. It was felt it was no longer necessary to have the definition of principal source of income as contained in the original section.

[Minister Abbott in reply to Mr. Macdonnell (Greenwood)] ... almost invariably these gentlemen farmers never make money from their farms. They always lose money; and they write off that loss against income from other sources, such as salary or investments. The section introduced last year was of course to limit that write-off to the lesser of the two figures mentioned.

- Relieving in the following two respects. First, the enactment of the restricted farm loss rules was relieving in the sense that it formalized a practice (truce) allowing for 50 percent deductibility that Revenue Canada sought to end. Presumably this truce related to Revenue Canada not applying strictly the deduction restrictions related to "personal and living expenses" and expenses not incurred "wholly, exclusively and necessarily" to earn income. Second, and possibly because of inadvertence on the government's part (see the comments of Thom, infra note 49), the codification of the practice removed the constraint restricting the deductibility of part-time farm losses to secondary sources of income. From this perspective, the restricted farm loss rule added to s. 13 of the 1948 Act brought relief to part-time farm losses by overriding the then chief source of income rule (such farm losses could offset a taxpayer's total income). No other type of secondary source loss was accorded similar treatment. This lends to a more fundamental review of the chief source of income rule (discussed above at point 6 in the body of the article).

See ss. 13(3) and (4) of the 1948 Act (added by S.C. 1951, c. 51, s. 4(1), applicable to the 1949 and subsequent taxation years).

See S.C. 1952, c. 29, s. 4, amending s. 13 of the 1948 Act, applicable to the 1952 and subsequent taxation years. Also see s. 13 of the 1952 Act. The chief source of income concept was retained only with respect to farming losses. Among other things, this removed the preferential treatment accorded part-time farm losses $v i s-\grave{a}$-vis secondary losses from other sources (see comments at supra note 46). The deduction of part-time farm losses as subsequently subject to restrictions not applicable to losses from other business income sources, which is what one could have expected to be the only outcome of the codification of Revenue Canada's administrative practice in 1951 (for further details, see supra notes 43 and 46 and infra note 49). 
[The unanswered question posed by Mr. Knowles, which was followed by members agreeing to the section and ending the related debate.]

Are there no gentlemen grocers or gentlemen druggists? ${ }^{49}$

Abruptly, taxpayers were permitted to total their income and losses from employments, offices, businesses, and property sources (and other sources) and use the net amount as their income base, subject to the "restricted farm loss" rules. By doing so, Parliament related a taxpayer's ability to pay tax in a taxation year to the taxpayer's overall gain from all sources of income for the year. This could also be said to encourage risk taking in the general economy for the benefit of all taxpayers. Yet, as noted previously, prior to 1972, no reference was made to losses in s. 3 of the 1948 Act and the 1952 Act, which provided the general rules for computing a taxpayer's total world income from sources that included businesses, property, offices, and employments.

No longer would a chief source of income approach be relied upon to constrain the deductibility of non-farm losses. This historic 1952 policy shift placed new pressure on the definition "personal or living expenses" and the more fundamental source of income concept.

\section{The Definition "Personal or [AND] Living EXPENSES" AND THE RELIEving NatURe OF THE "REASONABle EXPECTATION OF PROFIT" TERMINOLOGY USED THEREIN}

Personal and living expenses have a historic connection to the source of income concept, the various forms of the "chief source loss constraint" rule, and the "reasonable expectation of profit" terminology (first used in the 1939 definition "personal and living expenses" in the 1927 Act (and in successor definitions)). For example, Parliament's concern with "personal and living expenses" dates back to 1917 and the use of that phrase in paragraph 3(1)(d) of the 1917 Act, which indicated that personal and living expenses were to be ignored when determining a taxpayer's income from a source. Therefore, consideration should be given to the use of the "reasonable expectation of profit" terminology in the 1939 definition and its relevance, if any, to

House of Commons Debates (27 May 1952) at 2626-27. The following was also stated in 1952 about the change:

This may have been an inadvertent policy development [the 1951 restricted farm loss rule that permitted farm losses to offset a chief source of income (see supra notes 45 and 46)], but it nevertheless broke the crust of policy which had been maintained intact so long. In any event, the fact seems to be that the government undertook to review the whole matter, with the result that the amendment last spring completely knocked out the proposition that income of a person should be deemed to be not less than his income from his chief source of income.

See Thom, supra note 40 at 17. 
the "reasonable expectation of profit" rule for the purpose of identifying the existence of a business or property as a source of income in a taxation year if the business or property produces a loss in the year.

\section{The PRE-1939 Statutory SCHEME for PERSONAL AND Living EXPENSES}

As noted, the for profit rule constraining the deductibility of losses from secondary sources was added in 1919 by the enactment of paragraph 3(f) of the 1917 Act. $^{50}$ At the same time, s. 3 of the 1917 Act was amended to be more specific with respect to personal and living expenses, and this was done by having a non-deduction rule and an income inclusion rule. Both of these rules (concerning personal and living expenses) were directed at profit computations in respect of a source of income. In particular, paragraph $3(1)(e)$ of the 1917 Act provided with respect to a source that:

(e) in determining the income no deduction shall be allowed in respect of personal and living expenses, and in cases in which personal and living expenses form part of the profit, gain or remuneration of the taxpayer, the same shall be assessed as income for the purposes of this Act. ${ }^{\text {st }}$

The non-deductibility aspect of personal and living expenses was carried over into paragraph $6(\mathrm{f})$ of the $1927 \mathrm{Act}$, and the rule applied to the computation of profits or gains from any particular income source including a business or property source. ${ }^{52}$

The income inclusion aspect of personal and living expenses in respect of a source was carried over into paragraph 3(e) of the 1927 Act and included in income:

(c) personal and living expenses when such form part of the profit, gain or remuneration of this taxpayer. $^{53}$

However, two 1938 cases highlighted deficiencies in these two rules from the perspective of the Crown. The Hatch ${ }^{54}$ case determined that the "chief position loss constraint" rule did not apply to investment profits of a personal corporation (the income of which was deemed to be income of its shareholders), which could be reduced by losses from a horse farm operation. Amending the then "chief position" rule to apply to a taxpayer's chief "source" of income would not have precluded the Hatch result. Rather, such a change would have restricted the deduction of the loss only if the investment source was a taxpayer's chief source of income. As a further wrinkle, the Hatch decision suggested that a corporation could not separate its investments from its business as freely as might be the case with an individual. ${ }^{\text {ss }}$

\footnotetext{
so $\quad$ See supra note 38.

s1 See S.C. 1919 , c. 55 , s. 2.

32 $\quad$ See the 1927 Act, supra note 3. Also see Owen, infra note 58 at 1013.

s. $\quad$ See the 1927 Act, supra notc 3.

s4 Supra note 39.

ss Ibid. (especially commentary in the C.T.C. headnote).
} 
Also, Malkin v. M.N.R. ${ }^{56}$ highlighted a deficiency in the "personal and living expenses income inclusion" rule in paragraph 3(e) of the 1927 Act. In particular, Mr. Malkin transferred to a trust for the benefit of his children insurance policies on his life, residential property, and preferred shares that he owned in a corporation he controlled. The corporation then paid dividends on the preferred shares to the trust, which used the receipts to pay the insurance premiums and maintain the residence in which Mr. Malkin continued to live free of charge. The Exchequer Court found that the income inclusion rule did not apply to Mr. Malkin even though he benefited from the payment of house maintenance expenses out of income earned by his corporation. This was because the living expenses were not emoluments (salary), nor were they received in addition to salary or other remuneration from a source. ${ }^{57}$

\section{THE 1939 DEFINITION "PERSONAL AND LIVING EXPENSES"}

Parliament responded in 1939 to the adverse decisions in the Hatch and Malkin cases $^{58}$ by:

- Adding a definition "personal and living expenses" in paragraph 2(r) of the 1927 Act, which provided an extended meaning. Obviously, paragraph $6(f)$ precluded the deduction of personal and living expenses. ${ }^{59}$ What it did not constrain was a taxpayer's deduction of non-personal expenses incurred to maintain property that was a source but which also had a personal use or enjoyment element.

- Broadening the circumstances in which "personal and living expenses" could be income. While paragraph 3(e) of the 1927 Act applied to personal and living expenses that formed part of the taxpayer's profit, gain, or remuneration from a source, it did not apply in Malkin-like cases.

1920-1940 D.T.C. 456; [1938-39] C.T.C. 128 (Ex. Ct.) [hereinafter Malkin].

lbid. (D.T.C. at 458-60; C.T.C. at 133-35).

John Owen makes a convincing case for the view that the drafter had in mind both the deductibility matter raised by the Hatch decision and the personal and living expenses income inclusion lacuna noted in Malkin, supra note 56. See J.R. Owen, "The Reasonable Expectation of Profit Test: Is there a Better Approach?" (1996) 44 Can. Tax J. 979 at 1008-14. The Malkin concern is reflected in all of paragraph $2(r)$ and in the amendment to the personal and living expenses income inclusion rule in paragraph 3(e) of the 1927 Act (referenced at infra note 60). Thus the drafter appears to have been seeking to accomplish at least two objectives. Which objective was of greater concern at the time is pure speculation.

Also see paragraphs 6(a) and (e) of the 1927 Act. Fien suggests paragraph 6(a) of the 1927 Act precluded the deduction of such expenses because they were "not wholly, exclusively and necessarily laid out or expended for the purpose of earning the income." See Fien, supra note 6 at 1293. However, in Samson v. M.N.R., [1943] C.T.C. 47 (Ex. Ct.) it was suggested (at 63) that apportionment was required in certain cases under paragraph 6(a); also see LaBrie \& Westlake, supra note 23 at $110-11$. Paragraph 6(e) precluded the deductibility of expenses in respect of "unproductive property or assets not acquired for the purpose of a trade, business or calling...." 
In conjunction with amending the income inclusion provision in paragraph $3(\mathrm{e})$ of the 1927 Act, $^{60}$ the inclusive definition stated:

(r) personal and living expenses shall include inser alia

(i) the expenses of properties maintained by any person for the use or benefit of any taxpayer or any person connected with him by blood relationship, marriage or adoption, and not maintained in connection with a business carried on bona fide for a profit and not maintained with a reasonable expectation of a profit;

(ii) the expenses, premiums or other costs of any policy of insurance, annuity contract or other like contract if the proceeds of such policy or contract are payable to or for the benefit of the taxpayer or any person connected with him by blood relationship, marriage or adoption.

The provisions of this paragraph (r) shall extend to expenses of properties and establishments maintained by a personal corporation, estate or trust for the benefit of any of its shareholders or beneficiaries."

The object of subparagraph 2(r)(i) of the 1927 Act was explained in the House of Commons from the perspective of precluding any taxpayer from deducting as a business expense any expenses incurred for maintaining properties. ${ }^{62}$ However, the example used referred to gentleman farming operations or stables not carried on bona fide for profit and not maintained with a reasonable expectation of profit. ${ }^{63}$ The provision indicated that certain otherwise deductible expenses incurred to maintain properties were non-deductible personal and living expenses in certain cases. In particular, the extended meaning of personal and living expenses applied to expenses incurred where properties were maintained for the use or benefit of any taxpayer or any person connected to the taxpayer by blood, marriage, or adoption, unless one of two conditions did not apply (described below as "exceptions"). One of the two exceptions applies, respectively, if:

(1) The "income inclusion" aspect of this rule was carried over into s. 3 of the 1927 Act but was amended in 1939 after the Malkin case to read as follows:

(c) personal and living expenses when such form part of the profit, gain or remuneration of the taxpayer or the payment of such constitutes part of the gain, benefit or advantage accruing to the taxpayer under any estate, trust, contract, arrangement or power of appointment, irrespective of when created. [Emphasis added]. See S.C. 1939, c. 46, s. 3.

Nevertheless, the amendment did not accomplish its object according to the follow-up decision in Malkin v. M.N.R., 1941-1946 D.T.C. 587; [1942] C.T.C. 135 (Ex. Ct.). Also see Owen's analysis of that case, supra note 58 at 1010-15.

(1) S.C. 1939 , c. 46 , s. 2.

(12 House of Commons Debates (24 May 1939) at 4467. Excerpted by Owen, supra note 58 at 1010.

(3) Ibid. 
- the properties were maintained in connection with a business carried on bona fide for "a" profit (i.e., "an" actual profit appears necessary ${ }^{64}$ ); and

- the properties were maintained with a reasonable expectation of profit.

It is difficult to envision how the second "reasonable expectation of profit" exception to the definition "personal and living expenses" has meaning in the context of the 1927 Act unless meant to be relieving. ${ }^{65}$ The Hatch $^{66}$ decision indicated that a business source could exist under the 1927 Act if the activity was carried on for profit, an approach that was analogous to the approach taken in 1919 to constraining losses from secondary sources (i.e., see paragraph $3(1)(f)$ of the 1917 Act). From this perspective, the second "reasonable expectation of profit" exception is relieving if the "for $a$ profit" phrase meant that a taxpayer satisfied the first exception only if the taxpayer had an actual profit in the taxation year under review. That is to say, the phrase "for a profit" was meant to refine the for profit test.

At first glance, this relieving approach appears to be inconsistent with the findings in the subsequent 1952 McLaughlin Estate ${ }^{67}$ case, which concerned the Crown's unsuccessful attempt to apply the 1939 definition "personal and living expenses" and thereby deny the deduction of farming losses. The Exchequer Court held in that case that, in 1944 and 1945, the taxpayer engaged in a business bona fide for profit, and he did this with a reasonable expectation of profit notwithstanding that the farm failed to produce a profit. However, the reasoning of the Court in the McLaughlin Estate case is unsatisfactory as to why the definition "personal and living expenses" did not apply. In particular, the Court approached the matter on the basis that the taxpayer would be successful only if both exceptions in the definition were met, and never considered important aspects of those exceptions. The approach taken was deficient in these three respects:

- as noted elsewhere, the extended meaning to personal and living expenses in the definition did not apply to a taxpayer if the taxpayer satisfied one of the two (not both) exceptions; ${ }^{68}$

- the Court did not consider whether the word "a" in the "business carried on bona fide for a profit" exception meant that an actual profit in each particular taxation year under review was necessary to meet the first exception in the definition in the year; and

For a different view, see Owen, supra note 58 at $981-83$ and Fien, supra note 6 at 1295. Owen maintains that the disjunctive nature of the amended definition "personal or living expenses" of the 1952 Act (and subsequent Acts) makes no sense. In particular, that the word "for" can only mean "with the purpose or object" of a profit and thereby adds nothing to the meaning of the word "business." Given this, Owen suggests that it is difficult to conceive how the "reasonable expectation of profit" exception could apply.

Ibid.

Supra note 39.

Supra note 44.

See Owen, supra note 58 at 1014-15. 
- the wrong question was asked with respect to applying the "reasonable expectation of profit" exception in the definition. In particular, the court did not ask whether the "farm property" had been "maintained" with a reasonable expectation of profit; it asked whether the "business" had a reasonable expectation of profit. 69

Moreover, the McLaughlin Estate case concerned provisions in the 1927 Act in which income from a source referred to profits received by a taxpayer from the source. This is important for two reasons. First, the Crown litigated only whether the definition "personal and living expenses" applied in the McLaughlin Estate case (i.e., implicitly conceding that the source of income existed). Second, the 1948 Act (and the 1952 Act) took a "profits therefrom" approach to computing profits of a business or property source, which appears to be an important factor in applying the revised definition "personal or living expenses" in the 1948 Act.

\section{THE 1948 DEFINITION "PERSONAL OR LIVING EXPENSES"}

In 1948, changes were made that revised the name of the definition to "personal or living expenses" and replaced:

- the words "for a profit" with "for profit" (in the "business for profit" exception); and

- the words "and not maintained" with "or" (in the "reasonable expectation of profit" exception).

There are four reasons why caution should be exercised when considering, from the perspective of the genesis of the "reasonable expectation of profit" rule, these 1948 changes to the definition "personal and living expenses." First, the 1948 Act included the general computation rule in s. 4 under which a taxpayer's income from a business or property source "is the profit therefrom." Under the 1948 and 1952 Acts, a separate source approach had to be taken for the purpose of applying the "profit therefrom" rule in s. 4 to each particular business or property source, including for the purpose of applying the "chief source of income" rule in s. 13 of those statutes. ${ }^{70}$ It was unclear whether a loss could be a source of income under then s. 13. Was a profit a necessary

That is to say, the approach is technically questionable given the then language of the provision. However, it is difficult to envision this distinction changing the outcome of the particular case. Further, the approach taken by the Court on this point is consistent with the wording used in the definition "personal or living expenses" in the 1948 Act. Owen suggests, supra note 58 at 1014-15, that the literal wording of the definition "personal or living expenses" in s. 248(1) of the Act may deny all expenses incurred with respect to a property not maintained in connection with a "business" carried on bona fide for profit or with a reasonable expectation of profit. Restated, that expenses incurred in respect of non-business use property having a personal use or benefit clement are "technically" not deductible even if the property has a reasonable expectation of profit. This was the case even if the 1973 James case, supra note 28 , is correct when it suggests that the income "from all sources" approach in s. 3 of those statutes negated the need that profits exist to have a source of income in the year. This was also the case even if the above mentioned Haich, supra note 39, and McLaughlin Estate, supra note 44, cases indicate that a loss could be a source of income under the 1927 Act. 
precondition to having a source of income for this purpose? The 1954 Robertson ${ }^{71}$ case would eventually consider this issue in the course of applying the "chief source of income" rule in s. 13 of the 1948 Act.

Second, if a current or past profit was a necessary precondition to having a source for the purpose of applying the chief source of income test in s. 13 of the 1948 and 1952 Acts, this was not necessarily the case for the purpose of computing income from a business or property source under ss. 3 and 4 of those Acts. Under those sections, a business could be a source because it is a business given that neither provision addresses the loss concept. If so, the reason for using the "for profit" and "reasonable expectation of profit" terminology could be to ensure that otherwise deductible expenses were deductible for the purpose of computing income (loss) from the business only where the taxpayer also satisfies one of two subjective-intent tests with respect to the business. First, one should distinguish maintaining a property for use in a taxpayer's business where the business in operated with a "tax avoidance or personal use" motive rather than with a "for profit" motive. Second, one should also ask whether the taxpayer has a reasonable expectation of profit from the business if the business is operated with a tax avoidance or personal use motive. In both cases, however, the business exists as a source of income under s. 3 of the 1952 Act.

Third, and as suggested in point two above, the substitution of the word "or" for the words "and not maintained" in the "reasonable expectation of profit" exception in the definition "personal or living expenses," meant that that exception remained relieving only if the property was maintained in connection with a business, as compared to a property source of income. This view is consistent with the above reasons and with the "business loss carryover" rules added in 1942 to the $1927 \mathrm{Act}^{72}$ and that applied to business losses only and which were placed in paragraph 26(1)(d) of the 1948 Act and paragraph 27(1)(e) of the 1952 Act.

Fourth, while the definition "personal or living expenses" constrained the deductibility of certain expenses incurred to maintain property, the "chief source of income loss constraint" rule ceased to apply to business losses post-1951 (other than farm losses). In the case of non-farm business losses, something more nebulous than a "chief source of income" rule would constrain their deductibility thenceforth: whether the loss is from a business source of income. The task of determining this was made more difficult by the income "from all sources" approach taken in s. 3 of the 1952 Act and the absence of the loss concept therein because both matters raised questions about the way in which the source of income concept applied to losses under that Act.

Thus, while it is correct to say that the first statutory use of the "reasonable expectation of profit" terminology was in an exception to the 1939 definition "personal and living expenses," it is wrong to conclude from this that the use of the terminology was meant to be non-relieving. Nor is it appropriate to conclude that the use of the terminology in that definition was the genesis for the broader objective "reasonable

72 See supra note 25. 
expectation of profit" rule in the case law that tests the existence of a business that produces a loss as a source of income under the post-1947 income tax statutes. Rather, the genesis relates to tackling the relationship of profit (loss) to the more fundamental source of income concept.

\section{E. The Evolution of the Case law that Culminated in the MOLDOWAN DECISION: CAN A LOSS BE A SOURCE OF INCOME? ANd Did Dickson J. MAKe an ERRor in the Moldowan Decision?}

From the perspective of the source of income concept under the post-1947 statutes, the "reasonable expectation of profit" rule is relieving or constraining with respect to business or property losses depending upon the issue and facts. Rather than rehash a myriad of cases reviewed in detail by others, this section refers to particular provisions of the tax law and cases interpreting that law. It asks and answers the following two questions:

- Can a loss be a source of income, and

- Did Dickson J. make an error about the "reasonable expectation of profit" test in Moldowan?

\section{CAN A LOSS BE A SOURCE OF INCOME?}

Under the provisions of the 1927 Act, the Hatch ${ }^{73}$ and McLaughlin Estate ${ }^{74}$ cases suggest that a loss from farming can be in respect of a business source of income if the farming is carried on for profit or with a reasonable expectation of profit. The Hatch case concerned the chief position rule and the McLaughlin Estate case concerned application of the definition "personal and living expenses," but matters differed under the 1948 Act.

The 1948 and 1952 Acts took a different statutory approach to competing income (loss). Three cases stand out in the evolution of the "reasonable expectation of profit" rule: Robertson, ${ }^{75}$ Dorfman v. M.N.R., ${ }^{76}$ and Moldowan. ${ }^{77}$

\section{The 1954 Robertson Case}

The Robertson case concerns a widow who inherited her husband's investments in 1932. Mrs. Robertson acquired a farm in 1948, having a total invested cost of $\$ 272,000$. In 1949 , Mrs. Robertson sought to reduce her $\$ 11,993$ income from investments by a $\$ 12,702$ farm loss (i.e., a net loss of $\$ 709$ ). Like other taxpayers in

73. Supra note 39.

$74 \quad$ Supra note 44. For a different view of the McLaughlin Estate case and other cases considered in this section of the article, sec Fien, supra note 6 at 1289-1301.

Supra note 9.

72 D.T.C. 6131 ; [1972] C.T.C. 151 (F.C.T.D.) [hereinafter Dorfman].

Supra note 2. 
1949, Mrs. Robertson's income could not be less than her income from her chief source of income, and the computation of her income was subject to, if applicable, the "restricted farm loss" rules enacted in 1951 (retroactive to 1949).

The Minister of National Revenue "determined" under then s. 13(2) (now s. 31(2)) that Mrs. Robertson's chief source of income was neither farming nor farming in combination with some other source. Mrs. Robertson's income was deemed to be not less than her income for the year from her chief source of income less the lesser of $\$ 5,000$ and one-half her farming loss (i.e., the farm loss restriction was applied). Mrs. Robertson appealed.

At the Tax Appeal Board stage of the litigation, ${ }^{78}$ the Board ruled that "chief source of income" meant "chief occupation," that Mrs. Robertson's chief occupation was farming, and that she was not, therefore, subject to the "chief source of income loss constraint" rule, nor to the "restricted farm loss" rule. The Minister appealed to the Exchequer Court.

The Exchequer Court made three key findings. First, the Court found that the Minister's determination under s. 13 of the 1948 Act was open to review because the provision did not provide that it was "final and conclusive," as was the case in s. 10 of the 1927 Act. Second, the Court determined that chief source of income did not mean chief occupation. Third, it held that Mrs. Robertson's chief source of income in the particular taxation year was not farming because it yielded a loss rather than a profit (i.e., the "no profit no source rule"). Potter J. stated:

The word "source" as used in the Act is a correlative term and there can no more be, at its inception, income without a source of income than there can be child without a mother, and the converse. There can, of course, be a potential source of income and, it is conceivable that, a taxpayer may ordinarily have a chief source of income which is farming but in a particular year suffer losses in his farming operations instead of profits and consequently have no income therefrom in that year. ${ }^{79}$

Nor was Mrs. Robertson's chief source of income found to be a combination of farming and some other source. Mrs. Robertson's income could not be less than that of her chief source, which was her investment income, less the restricted farm loss amount.

The overall result appears correct because Mrs. Robertson's chief source of income was not farming nor farming in combination and some other source. Unfortunately, the Court's reasoning yielded a result that was perhaps unanticipated. To apply s. 13, Potter J. need only have concluded that Mrs. Robertson's chief source of income was not farming nor farming in combination with her investment source, with the result that the "restricted farm loss" rule would have applied. By conditioning a source on the existence of a current year profit, the effect of the Robertson decision was to deny parttime and full-time farmers their full farming losses. Potter J. took a plain meaning 
approach to then s. 13. That the result was questionable was noted in the Carswell Editorial Comment accompanying the Robertson decision:

The practical effect of this decision ... may be to limit the amount deductible in respect to farming losses to the lesser of $\$ 5,000$ or one half of the farming loss before depreciation if farming cannot be a source of income in a year of loss. In view of the original purpose of Section 13 of the Act, which was to limit the deductibility of farming losses by so-called hobby [part time] farmers, it would appear that some amending legislation is required to ensure that persons carrying on farming operations as a business are not penalized merely because they receive income from other businesses or investments.

No such amendment was made and the Robertson decision was followed in a number of subsequent cases. ${ }^{81}$

A competing view of the business source of income issue emerged, however, over the next three decades. In 1964, the Exchequer Court implied in Stewart v. M.N.R. ${ }^{82}$ that raising show dogs could be a business source of income if it was carried on in good faith with a reasonable expectation of profit. ${ }^{83}$ (The taxpayer hoped to use the dogs in his advertising display business.) A similar suggestion was made in 1971 in C.B.A. Engineering v. M.N.R. ${ }^{84}$ about an expectation of profit, which concerned farming losses and a separate civil engineering consulting business. ${ }^{85}$ However, neither case addressed directly the source of income question.

Another decision rendered in 1971 provided an interesting twist on the source of income question. There the taxpayer owned a half interest in a racehorse that earned significant profits. The Court rejected the Minister's assessment, which included net winnings in the taxpayer's income, on the basis that the profits were an unexpected

Ibid., C.T.C. at 111.

For example, see MacIntosh v. M.N.R., 54 D.T.C. 356; (1954), II Tax A.B.C. 95 (T.A.B.); No. 362 v. M.N.R., 56 D.T.C. 499 ; (1956), 16 Tax A.B.C. 60 (T.A.B.); Bara v. M.N.R., 61 D.T.C. 715 ; (1961), 27 Tax A.B.C. 33 (T.A.B.). But see Grieve v. M.N.R., 57 D.T.C. 574 (T.A.B.) (hereinafter Grieve], in which the Board held that farming was ordinarily Grieve's chief source of income in 1952 and 1953 despite losses in those years from apple farming. Mr. Grieve had farmed the land since 1907, with fluctuating income until 1947 when losses began to occur (except 1950) because severe weather killed a number of apple trees.

64 D.T.C. 5023; [1964] C.T.C. 45 (Ex. Ct.). Noel J. found that:

- the restricted farm loss rules did not apply because the dog activity was not farming,

- the expenses were too remote to be considered deductible in the context of the advertising business, and

- the expenses were within the meaning of the definition "personal or living expenses."

Ibid. (D.T.C. at 5027; C.T.C. at 51). However, Noel J. relied on the McLaughlin Estate case, supra note 44, which concemed the definition "personal and living expenses" in the 1927 Act rather than the source of income concept. Also see the discussion in section $C$ of this Part.

71 D.T.C. 5282; [1971] C.T.C. 504 (F.C.T.D.), set aside by the Federal Court of Appeal at [1974] C.T.C. $888 \# 3$ and referred back to the Trial Court to consider the issue of whether the taxpayer's chief source of income was a combination of farming and some other source. The Trial Court had applied s. 13 to limit the deduction of the farming loss from the income earned by the civil engineering business.

lbid. (D.T.C. at 5286; C.T.C. 509-10). 
windfall not earned in the context of a business. ${ }^{86}$ One can only speculate whether Revenue Canada thought about the result and started reconsidering the deductibility of loss cases from the perspective of "what's good for the goose is good for the gander."

\section{The 1972 Dorfman case}

In 1972, the Dorfman ${ }^{87}$ decision applied "reasonable expectation of profit" terminology in rejecting the "no profit no source" rule rendered two decades earlier in the Robertson case.

The key issue before the Court was whether a loss could be a source of income. The taxpayer operated a retail fur business and a mink farm separately from each other. The taxpayer also had rental income. The mink farm sustained losses of $\$ 5,434$ and $\$ 11,604$ in 1965 and 1966, respectively. The farm had earned, however, net income in many of its previous years of operation. Conversely, the fur operation earned income in 1965 and 1966 of $\$ 7,890$ and $\$ 11,091$, respectively. The fur operation had, however, realized losses in many of its previous years of operation. Only in 1956 and 1957 had the taxpayer's income from farming exceeded the taxpayer's income from other sources.

The Minister did not apply then s. 13(2) to determine the taxpayer's chief source of income. Rather, the Minister limited the taxpayer's deduction of farm losses in 1965 and 1966 on the basis that the taxpayer's chief source of income in those years was neither farming nor a combination of farming and some other source. The Tax Appeal Board dismissed the taxpayer's appeal and the taxpayer further appealed to the Exchequer Court.

Counsel for the Crown contended that the mink farm of the taxpayer could not be a source of income for an affected taxation year unless the taxpayer had a net farming income for the year. In making this argument, the Crown relied on the 1954 Robertson "no profit no source" rule notwithstanding the fact that significant income from the mink farm operation existed in the Dorfman fact pattern in eight of the thirteen taxation years ending before the two taxation years under review. ${ }^{88}$ In rejecting this argument, Collier J. stated:

I cannot accept the interpretation put by counsel for the Minister in this case on the words "source of income": that there must be net income before there can be a source. In my view the words are used in the sense of a business, employment, or property from which a net profit might reasonably be expected to come."

See Hammond v. M.N.R., 71 D.T.C. 5389; [1971] C.T.C. 663 (F.C.T.D.) [hereinafter Hammond]. Note: the Crown failed to argue in the Hammond case that the race horse was property and there was profit therefrom, half of which was income of Mr. Hammond to be included under and ss. 3 and 4 of the 1952 Act.

Supra note 76.

Ibid. (D.T.C. at 6133; C.T.C. at 152).

Ibid. (D.T.C. at 6134; C.T.C. at 154) [emphasis added]. Also see the comments of S. Silver, "Great Expectations: Are They Reasonable?" (Real Estate Transactions: Tax Planning for the Second Half of the 1990s, Corporate Management Tax Conference, Toronto, June 1995) (Toronto: Canadian Tax Foundation, 1996) 6:1 at 6:6-7. 
The effect of the Dorfman decision was to ensure that the existence of a business source of income is not dependent on a profit earned in the current year, if profit might reasonably be expected. It is unclear what importance the existence of significant past income had in the outcome, but such income certainly provided the Court with evidence that the taxpayer's business could earn significant profits, at least in prior taxation years. The result was a more flexible rule to test the existence of a business or property source of income.

The Crown also argued that the mink pelts were not used in the furrier business. However, Collier $\mathrm{J}$. found that Dorfman's chief source of income was farming in combination with another source. In doing so, the Court rejected the Crown's contention that there need be a relationship or connection between sources of income to find that a taxpayer's chief source of income is a "combination of farming and some other source of income."

The tax law in respect of restricted farm losses had almost come full circle. The 1954 Robertson ${ }^{90}$ decision inappropriately subjected full-time farmers to the farm loss rules. Conversely, the 1971 Dorfman decision had the potential to negate the limitations on the deductibility of farm losses for part-time farmers because it failed to articulate the way in which sources were to be combined when applying the chief source of income test. To which farmers would the restricted farm loss rules apply? Nevertheless, the Dorfman and Robertson cases had at least one thing in common; neither case adequately respected the object and spirit of the restricted farm loss rules.

Dorfman and Robertson provided competing approaches to the source of income question and the chief source of income farming combination test. The Supreme Court of Canada would be called upon to clarify matters, and in the process a new debate emerged over the parameters of the reasonable expectation of profit rule. ${ }^{91}$

\section{The 1977 Moldowan Case}

The Moldowan decision clarified the meaning of the restricted farm loss rules in $\mathbf{s}$. 13 of the 1952 Act (s. 31 of the present Act). ${ }^{92}$ From the perspective of the underlying

Supra note 9.

91 Fien suggests that the dispute first emerged in the following two Federal Court Trial Division decisions rendered in 1973: James, supra note 28 and Holley v. M.N.R., 73 D.T.C. 5417 ; [1973] C.T.C. 539 (F.C.T.D.). See Fien, supra note 6 at 1298-99. In the Holley case, horse-racing losses were non-deductible because the undertaking was not maintained for profit or with a reasonable expectation of profit. For a rather interesting lead in to the Holley decision, see the Hammond case, supra note 86.

[T]he Income Tax Act as a whole envisages three classes of farmers:

(1) [A] taxpayer for whom farming may reasonably be expected to provide the bulk of income or the centre of work routine. Such a taxpayer, who looks to farming for his livelihood, is free of the limitation of s. 13(1) [of the $1952 \mathrm{Act}$ ] in those years in which he sustains a farming loss.

(2) [T] he taxpayer who does not look to farming, or to farming and some subordinate source of income, for his livelihood but carried on farming as a sideline business. Such a taxpayer is entitled to the deductions spelled out in s. 13(1) in respect of farming losses. 
source of income question, suffice to repeat the following oft-quoted dictum of Dickson J.:

Although originally disputed, it is now accepted that in order to have a "source of income" the taxpayer must have a profit or a reasonable expectation of profit. Source of income, thus, is an equivalent term to business: Dorfman v. M.N.R. [supra note 72] ...

There is a vast case literature on what reasonable expectation of profit means and it is by no means entirely consistent. In my view, whether a taxpayer has a reasonable expectation of profit is an objective determination to be made from all of the facts."

Note that this dictum provides that a business that earns a profit is a source of income, as is a business that does not earn a profit but that has a reasonable expectation of profit. This "reasonable expectation of profit" approach provides for a significantly more flexible and complex determination of the existence of a source of income, which can cut for or against a taxpayer depending on the issue and facts. It has been suggested, however, that the objective "reasonable expectation of profit" rule emerged almost by accident ${ }^{94}$ out of an error made by Dickson J. about the source of income concept in the 1952 Act. ${ }^{95}$

\section{Did DiCKSON J. MAKE AN ERROR ABOUT THE "REASONABLE EXPECTATION OF PROFIT" RULE IN MOLDOWAN?}

The basis of the purported error relates to the reliance of Dickson J. on the reasoning of Collier J. in the Dorfman ${ }^{96}$ case for the proposition that a source of income of a taxpayer must have a profit or a reasonable expectation of profit. The error is said to be an error in logic. In particular, if one concludes that every activity that has a reasonable expectation of profit is a source of income, this conclusion does not by itself mean it is correct to conclude that every source of income must have a reasonable expectation of profit. ${ }^{97}$

(3) [T] he taxpayer who does not look to farming, or to farming and some subordinate source of income, for his livelihood and who carried on some farming activities as a hobby. The losses sustained by such a taxpayer on his non-business farming are not deductible in any amount.

See S.C.R. at 487-88; D.T.C. at 5216; C.T.C. at 315. Further, the reference to a taxpayer whose source of income was a "combination" of farming and some other source was found to refer to category one farmers only. Thus, while Dickson J. found that there was no need for sources to be connected (as noted in Dorfman, supra note 76), the chief source test is met only if farming is done in "combination" with a subordinate source of income (i.e., the mere adding of two sources is not sufficient).

Supra note 2 (S.C.R. at 485; D.T.C. at 5215; C.T.C. at 313) [footnotes omitted].

B.S. Nichols, "Chants and Ritual Incantations: Rethinking the Reasonable Expectation of Profit Test" (Report of Proceedings of the Forty-Eighth Tax Conference, Montreal, 25-27 November 1996) (Toronto: Canadian Tax Foundation, 1997) 28:1 at 28:47.

Ibid. at 28:2-5.

Supra note 76.

Supra note 94 at 28:4-5. 
In the case of a business that incurs a loss in a taxation year, however, the Dorfman case does not necessarily stand for the proposition that a business that has a reasonable expectation of profit is a source of income in the year. This is because significant past income from the business existed in Dorfman with losses being present in the years under review. Thus, in a business loss case, the Dorfman decision may suggest that significant past income from a business must exist before one can ask whether the loss is deductible because the business has a reasonable expectation of profit in the year under review.

Arguably, then, the pure logic of the reasoning the Moldowan may admit to weakness. However, by placing in context the evolution of the statue and case law, one is better placed to determine whether the decision's outcome - that a business or property that incurs a loss is a source of income only if it has a reasonable expectation of profit - is a proper one. Recall that the dictum of Collier J. sought to revisit the Robertson decision's no profit no source rule respecting the "chief source of income loss constraint" rule. This article previously addressed (see paragraphs C and D of this Part) the ways in which the statutory law on computing income evolved from 1917 to 1972. Dickson J.'s approach ensures that loss offsets claimed by particular taxpayers from a business activity are not denied so long as the business satisfies the objective "reasonable expectation of profit" rule. Conversely, an activity that produces a loss is not a business source of income unless the business has a reasonable expectation of profit. Accordingly, taxpayers cannot claim a tax benefit by reducing their income base by deducting losses produced by a business or property that does not have a reasonable expectation of profit.

Moldowan and Dorfman were decided in the context of the wording of the pre-1972 statutory rules and cases interpreting those rules. Moldowan and Dorfman should also be considered from the perspective of the wording of the post-1971 statutes. Is it appropriate to consider only the words of s. 9(1) and paragraph 3(a) of the Act, thereby ignoring s. 9(2) and paragraph 3(d), for the purpose of finding or refuting the existence of the "reasonable expectation of profit" rule under the present Act? The next part of this article suggests that the answer to this question is "no."

\section{Sections 3 ANd 9 of the ACT ANd the 1996 TONN CASE ApPlying the "Reasonable Expectation of Profit" Rule}

This part considers:

- the wording of ss. 3 and 9 of the Act and the concepts of loss and source of income under those provisions;

- the Federal Court of Appeal decision in Tonn, ${ }^{98}$ and

- commentary on the Tonn decision and other decisions of the Federal Court of Appeal. 
The analysis below suggests that legislative support for the "reasonable expectation of profit" rule can be found in ss. 3 and 9 of the Act.

\section{A. SeCtions 3 AND 9 OF THE ACT}

Determining how ss. 3 and 9 of the Act apply to a taxpayer's business or property is fundamental to including an income (loss) from each business or property source of income for a taxation year into the taxpayer's income for the year. The business or property source of income concept is expressly referred to in both ss. 3 and 9 of the Act (also see s. 4, once it is determined a source exists). Interpretative disputes can arise from the use in ss. 3 and 9 of the following terminology: "income," "business or property," "is the taxpayer's profit from that business or property," "source," and "loss." The meaning and interrelationship of this terminology is central to disputes over how the source concept in s. 3 applies in the context of:

- a business or property under s. 9;

- the specific rules in the Act that adjust a taxpayer's profit (loss) from a business or property to "statutory income (loss)" to which s. 9 applies; and

- paragraph 3(d) if a statutory loss is computed from the business or property.

With respect to the source of income concept, paragraph 3(a) does not take the "income is the profits received by a taxpayer" approach taken in the 1927 Act, nor the "income is income from all sources" approach taken in s. 3 of the 1948 and 1952 Acts. ${ }^{100}$ Under the post-1971 law, a taxpayer's income for a taxation year is determined by various rules including the following requirements in s. 3 to:

(a) determine the total of all amounts each of which is the taxpayer's income for the year (other than a taxable capital gain from the disposition of a property [sce paragraph 3(b)]) from a source inside or outside of Canada, including without restricting the generality of the foregoing, the taxpayer's income for the year from each office, employment, business and property,...

(d) determine the amount, if any, by which the amount determined under paragraph $c$ exceeds the total of all amounts each of which is the taxpayer's loss for the year from an office, employment, business or property or the taxpayer's allowable business investment loss for the year...."1!1

While Parliament has defined "business" and "property" in s. 248(1) of the Act, it has not defined "income" nor "source" and has been especially muted on the principles to be used to compute a taxpayer's "profit (loss)" from a business or property source for a taxation year. This is understandable, as Parliament cannot hope to know the subtle differences existing in the myriad of arrangements existing in the economy - flexibility is therefore required. Parliament has implicitly relied on the expertise and common sense of the judiciary to develop, adapt, and refine general principles over time for application to specific circumstances. In this way, understandable objective standards evolve to constrain the foibles of uncertainty and apply the law to fact patterns in a generally rational, consistent, and fair manner on a case-by-case basis. Recall that the 1973 James case, supra note 28 , suggested that the income "from all sources" approach taken in the 1952 Act abrogated the view that there must be income in the sense of profit for there to be a source of income. 
Thus, s. 3 of the Act takes a source-by-source approach to income with a totalling of such separate amounts occurring. Reference should also be made to s. 4 , which requires taxpayers to make certain assumptions when computing income or loss from a source. Section 3 has, post-1971, enunciated in paragraph 3(d) an internal loss offset rule to the income base. A taxpayer's income for a taxation year is reduced by the total of amounts each of which is a loss to the taxpayer for the year from an office, employment, business or property, or allowable business investment loss. Moreover, while paragraph $3(\mathrm{~d})$ of the Act contemplates the deductibility of a taxpayer's business or property loss from other income, it is not appropriate to conclude that a loss is from a business or property source of income if there is no profit from the source to which s. 9(1) and paragraph 3(a) has applied. Rather, additional detailed consideration must be given to the scheme and object of the Act and the facts of any particular case.

In this regard, one must consider the meaning of the inclusive definition "business" and exhaustive definition "property" in s. 248(1) of the Act to ensure that a taxpayer has a business or holds property for the purposes of the Act. But this is but one step in the process. One must go further and relate the source of income concept in s. 3 (and s. 4) to the "profit and loss computation" rules as they apply to a particular business or property. Consideration should also be given to the provisions of the Act, if any, that negate the effect of the source of income concept.

In the case of a taxpayer's income (loss) from a business or property, the taxpayer's s. 9 "statutory income (loss)" from each business or property for a taxation is, subject to Part I adjustments, the taxpayer's profit (loss) from the business or property for the year. Section 9 of the Act states:

9. (1) Subject to this Part, a taxpayer's income for a taxation year from a business or property is the taxpayer's profit from that business or property for the year.

(2) Subject to section 31, a taxpayer's loss for a taxation year from a business or property is the amount of the taxpayer's loss, if any, for the taxation year from that source computed by applying the provisions of this Act respecting computation of income from that source with such modifications as the circumstances require.

(3) In this Act, "income from a property" does not include any capital gain from the disposition of that property and "loss from a property" does not include any capital loss from the disposition of that property. ${ }^{102}$

At least two points should be made about this wording. First, there is no business or property for profit test in s. 9, as was the case in paragraph 3(1)(f) of the 1917 Act which applied for the purpose of constraining the deductibility of losses from secondary sources. Thus, the question of whether a taxpayer's business or property is a source of 
income should not be framed in terms of the taxpayer's subjective profit motive or subjective profit expectation. Rather, the initial focus of the modern-day enquiry under s. $9(1)$ is on the profit of a taxpayer's business or property, which becomes income of the taxpayer to which s. 3 applies.

Second, ss. 3, 4, and 9 each reflect income and loss amounts and expressly refer to the source of income concept (unlike the pre-1972 statutory provisions). The words "from that source" in s. 9(2) therefore drive home the point that it is not any loss that satisfies s. 9 and paragraph 3(d). ${ }^{103}$ The loss must be from a business or property that is a source of income. This is more obvious when one asks whether a property is a source of income. One would not presume a property to be a source (e.g., a cottage); in the absence of a profit, something more is necessary.

In particular, the business or property loss rule in s. 9(2) expressly provides that a taxpayer's "statutory loss" from the business or property must result from applying the specific provisions of the Act respecting the computation of income from that source, with such modifications as the circumstances may require. This raises two related points:

- First, a loss calculation must respect s. 9(1) of the Act. That is to say, the s. 9(2) loss calculation must be in respect of a business or property for which there is "profit from that business or property." And the circumstances do not require that the "profit" reference in s. 9(1), which is to be computed by applying well-accepted business principles and the case law, be modified to be read as "loss." Among other things, this is because:

- $\quad$ s. 9(2) appears to already refer to a "loss" from the source (computed under well-accepted business principles); the first reference to loss in s. 9(2) is to a statutory loss, with the second reference being to a loss computed under wellaccepted business principles; and

- a taxpayer's s. $9(1)$ profit or a s. $9(2)$ loss (computed by applying wellaccepted principles of good business practice in respect of a source) can, once

In Hickman Motors v. M.N.R., [1997] 2 S.C.R. 336; 97 D.T.C. 5363; [1998] I C.T.C. 213 (S.C.C.) [hereinafter Hickman Motors], the minority opinion of Madame Justice L'Heureux-Dubé does not adequately reflect the fact that no amount is deductible under the Act vis-à-vis a purported business source if, in fact, no such source exists at law. In particular, the following was stated:

In my view, the words and scheme of the ITA support an application of the "reasonable expectation of profit" criteria to ascertain whether a taxpayer is carrying on a business or hobby, but not to determine the deductibility of CCA per se. See generally J.R. Owen, [supra note 58] ...

Reviewing the evidence through the appropriate prism, it is clear that the property produced revenue. (See D.T.C. at 5372-74; C.T.C. at 238-4I) [footnotes omitted].

With all due respect to Madame Justice L'Heureux-Dube, it is not sufficient to say that a capital cost allowance deduction may be claimed merely because it is in respect of a property that produces "gross" revenue. To satisfy s. 9 of the Act, the deduction must be in respect of a business or property that is a source of income. Revenue is but one of many factors to be considered in this regard. Also see infra note 104, which comments on non-commercial transactions. 
adjusted to reflect more specific rules enunciated in the Act and the case law, become "statutory income" to which s. 9(1) and the income inclusion rule in paragraph 3(a) apply. Similarly, a taxpayer's s. 9(1) profit or a s. 9(2) good business practice loss may, once adjusted to reflect more specific rules enunciated in the Act and the case law, become a "statutory loss" to which s. 9(2) and the loss offset rule in paragraph 3(d) apply; may in the sense that the deductibility of a s. 9(2) statutory loss is subject to the existence of the underlying source, with a business or property that earns a profit in a taxation year being a source of income in the year. ${ }^{104}$

- Second, it is not entirely certain that s. 9(2) can apply to a business or property that has not had profit to which s. 9(1) has applied.

However, s. 9(2) supports the testing of the existence of a business or property source with the "reasonable expectation of profit" rule when read in conjunction with s. 9(1) and paragraph 3(d). In particular, there are three possible approaches to interpreting s. 9. First, the "reasonable expectation of profit" rule is an unreasonable construction (which is an interpretative approach advocated by many). This approach should be rejected for the reasons provided throughout this article. A second approach is that a statutory loss from a business or property to which s. 9(2) applies exists only if the business or property has a profit in the current year that is adjusted by the Act to a statutory loss; or, if not, has substantial past profits with profit reasonably expected. That is to say, a business or property is a source in such cases only if substantial past profits exist and the rule is met in the current year. Recall in this regard that significant past income existed in Dorfman. ${ }^{105} \mathrm{~A}$ third approach is that a business or property is a source in a taxation year if there is a profit from the business or property in the year under review, or there is a reasonable expectation of profit (computed under well-accepted business principles). This is the Moldowan test.

Generally, a source would exist in cases where provisions of the Act convert a good business practice loss into a statutory income, or convert a good business profit into a statutory loss. However, consideration should also be given to non-commercial transactions and to anti-avoidance rules that may apply. For the relevance of non-commercial transactions, see Part IV of this article. Suffice for now to note that where a taxpayer has a business or property source of income and includes in the source's income (loss) computation deductions related to a non-commercial transaction(s), that the taxpayer treats as being within the ambit of the source, a more complex issue arises. The issue is whether the deductions purported to arise under the Act in respect of the non-commercial transactions may be included in (or must be excluded from) the s. 9 profit (loss) and income (loss) computation. Ignoring the general anti-avoidance rule in s. 245, expenditures related to non-commercial transactions should have to be excluded from a source's profit (loss) income (loss) calculations for two related reasons. First, transactions must come within the ambit of the source. Second, well-accepted business principles (interpretative aids) include noncommercial expenditures within the ambit of a source only if one accepts the (unlikely?) proposition that non-commercial expenditures reflect well-accepted business principles, and then only if the presiding judge accepts that such an interpretive aid (if it were to exist) should be followed in the particular case. For the relevance of well-accepted business principles and the most accurate picture of income (loss), sec the Canderel case, infra note 111. With respect to statutory adjustments to profit (loss) calculations, see the discussion in Part IV of this article.

Supra note 76 (D.T.C. at 6133 ; C.T.C. at 152). Both the mink farm and the furrier business earned net income in taxation years ending prior to the years under review. Past net income also existed in the Moldowan fact pattern (see supra note 2; S.C.R. at 484; D.T.C. at 5214; and C.T.C. at 312) and the Grieve fact pattern (see supra notc 81 at 575). 
The second "no source if there were no substantial past profits" approach to interpreting $s .9$ could be correct if a literal or plain meaning approach were taken when considering the source reference in s. 9(2) and interpreting its relationship to the phrase "is the taxpayer's profit from that business or property" in s. 9(1). The Crown does not appear to have yet applied such a literal and narrow approach to the deductibility of a business or property loss under s. 9(2) and paragraph 3(d) of the Act. This may be because the "no source if there were not substantial past profits" approach would be deficient in at least three fundamental respects.

First, applying the "no source if there were no substantial past profits" approach to statutory s. $9(2)$ business or property losses would be a variation of the Crown's position rejected in Dorfman by Collier J., with Dickson J. relying on the Dorfman approach to craft in the Moldowan case a more flexible rule of law. Restated, applying such a literal interpretive approach to s. 9(2) loss cases would be regressive development in the law, no less simplistic and arbitrary than the "no profit no source" Robertson ${ }^{106}$ approach.

Second, applying the "no source if there were not substantial past profits" approach would not explain the use of the "reasonable expectation of profit" terminology in the Act to limit the flow-through of certain corporate tax effects on an acquisition of control. For example, the restriction on loss carryovers in paragraph 111(5)(a) (also see paragraph $88(1.1)(e)$ ) of the Act ensures that a corporation's non-capital losses from carrying on a business in taxation years ending before an acquisition of control survive the acquisition of control only if, among other things, the business is carried on by the corporation for profit or with a reasonable expectation of profit throughout the particular taxation year ending after the change of control in which the loss is being deducted. Paragraph $111(5)(b)$ provides a similar rule in respect of business losses arising in taxation years ending after the acquisition of control which would otherwise be available for carryback purposes. As is the case with the definition "personal or living expenses" in s. 248(1) of the Act, the focus point of this "reasonable expectation of profit" terminology is on a taxpayer's intent - in this case, with respect to the business of the corporation of which control is acquired. This focus ensures, among other things, that business losses of a corporation do not necessarily flow through for application against post or pre-acquisition of control income of the corporation even if the business had a reasonable expectation of profit in the years in which those losses were produced and in the year(s) in which the losses are being deducted. One answer to the question of what, if anything, this type of taxpayer subjective-intent test adds to the objective "reasonable expectation of profit" rule that applies to the business is as follows.

Unless the taxpayer subjective intent-based "for profit" and "reasonable expectation of profit" terminology were used in the acquisition of control loss flow-through rules, it could be argued that a corporation's pre or post-acquisition of control business losses could flow-forward or flow-back an acquisition of control without regard to whether the corporate taxpayer operated the business for profit (compare a "for profit" purpose with a "tax avoidance" purpose) or with a reasonable expectation of profit in the 
taxation year(s) in which it deducts the carryover losses from income from the business (or from income of the business and income from a similar business referred to in paragraphs $111(5)(a)$ and (b)). Allowing a non-capital loss flow-through in limited circumstances addresses the government's job retention objectives for a failing business that may survive if reinvigorated by a person with a plan better suited for success and who acquires control with the intent of saving the business from failure. Corporate noncapital losses do not flow-through an acquisition of control where the business is closed or the corporation does not carry on the business for profit or with a reasonable expectation of profit.

Third, applying the "no source if there were no substantial past profits" approach would be inconsistent with the object of having the income base in s. 3 reflect a taxpayer's total income. This is especially the case when contrasted with the pre-1952 rules that ensured a taxpayer's income was not less than the taxpayer's chief source of income (or if contrasted with an approach that applied tax to each particular source of income that results in an income or gain). The post-1951 object of s. 3 relates both to connecting a taxpayer's ability to pay tax to the taxpayer's overall economic gain for a year and to encouraging risk taking in the general economy for the benefit of all taxpayers. Making business or property loss offsets contingent on a current or past profit from the business or property would undermine those objects.

It is indeed ironic, however, that it is the object and spirit of the wording of all of s. 9 read in conjunction with s. 3 that appears to sanction the deduction under paragraph 3(d) of a loss from business or property that has yet to produce a profit. This is ironic because many of those who question the "reasonable expectation of profit" rule adhere to either the archaic or modern judicial plain meaning approach to interpreting tax legislation, ${ }^{107}$ an approach that led to the "no profit no source" Robertson rule. Nevertheless, it would be improper to interpret ss. 9 and 3 in a manner that would require all taxpayers to subsidize the unrealistic expectations of particular taxpayers. ${ }^{108}$ The legal rule judicially developed ${ }^{109}$ to test the existence of a business or property as a source of income is that there be a profit in the year, or a reasonable expectation of [a good business practice] profit.

At least three additional points should be made about the wording of s. 9. First, s. 9 and its predecessors fail to indicate the method to be used by a taxpayer to first determine the taxpayer's profit (loss) from a business or property other than to exclude capital gains from the disposition of property from a property's income. This has lead to a significant body of case law in the four areas mentioned by former Justice Jackett

For an article that critiques the modern interpretative approach to plain meaning, see B.J. Arnold, "Statutory Interpretation: Some Thoughts on Plain Meaning" (Report of the Proceedings of the Fiftieth Tax Conference, Toronto, 25-28 October 1998) (Toronto: Canadian Tax Foundation, 1999) 6:1.

Conversely, C. Fien argues for a "good faith intention and business behaviour [conduct] approach" albeit a taxpayer's expectations might be unrealistic when objectively considered (supra note 6 at 1308-15). 
and previously noted. ${ }^{110}$ With respect to the computation of profit (the fourth area), the most recent culmination in the case law is enunciated in a 1998 trilogy of cases decided by the Supreme Court of Canada: Canderel v. M.N.R., "' Toronto College Park v. M.N.R., ${ }^{112}$ and Ikea v. M.N.R. ${ }^{113}$

See the comment of W.R. Jackett referenced at supra note 34.

[1998] I S.C.R. 147; 98 D.T.C. 6100; [1998] 2 C.T.C. 35 (S.C.C.; lacobucci J. with Gonthier, Cory, Major, and Bastarache, JJ. concurring) [hereinafter Canderel]. Iacobucci J. summarized the computation of s. 9 income as follows:

(1) The determination of profit is a question of law.

(2) The profit of a business for a taxation year is to be determined by setting against the revenues from the business for that year the expenses incurred in earning said income....

In seeking to ascertain profit, the goal is to obtain an accurate picture of the taxpayer's profit for a given year.

(4) In ascertaining profit, the taxpayer is free to adopt any method which is not inconsistent with

(a) the provisions of the Income Tax Act;

(b) established case law principles or "rules of law"; and

(c) well-accepted business principles.

5) Well-accepted business principles, which include but are not limited to the formal codification found in G.A.A.P., are not rules of law but interpretative aids. To the extent that they may influence the calculation of income, they will do so only on a case-by-case basis, depending on the facts of the taxpayer's financial situation.

On reassessment, once the taxpayer has shown that he has provided an accurate picture of income for the year, which is consistent with the Act, the case law, and well-accepted business principles, the onus shifts to the Minister to show either that the figure provided does not represent an accurate picture, or that another method of computation would provide a more accurate picture.

See S.C.R. at 174-75; D.T.C. at 6109-10; and C.T.C. at 54-55. The taxpayer deducted a leasehold inducement payment in the year made to a tenant. The Court rejected the matching principle as a rule of law, and the Court allowed the deduction after applying the above principles. [1998] 1 S.C.R. 183; 98 D.T.C. 6088; and [1998] 2 C.T.C. 78(S.C.C.) [hereinafter Toronto College Park]. The taxpayer sought to deduct a leasehold inducement payment in the year made to obtain a tenant. The Court applied Canderel and found that the amount was deductible. [1998] I S.C.R. 196; 98 D.T.C. 6092; and [1998] 2 C.T.C. 6I(S.C.C.) [hereinafter Ikea]. Unlike the Canderel and Toronto College Park decisions, the lkea case concerns the revenue side of the profit equation (i.e., the taxpayer received an inducement payment). The Court found that the amount was received on income account and not capital account and that the amount was "realized" as income in the year received. Notwithstanding this, it appears the Court tempered its earlier decision in M.N.R. v. Friedberg, [1993] 4 S.C.R. 285; 93 D.T.C. 5507; [1993] 2 C.T.C. 306 (S.C.C.) [hereinafter Friedberg], which was not cited in the Ikea case. In the Friedberg case, the Court concluded that a taxpayer's losses from one leg of straddle transactions were deductible because they had been realized but gains from the related leg of each transaction need not be reflected in the profit calculation because they had yet to be realized. This approach can be inconsistent with the legal rule that requires taxpayers and the Minister to determine the most accurate picture of profit for a business in a taxation year. The Ikea decision may mean that the Court is leaving open for future review business aspects (such as "earned" profits) of complex business strategies related to buying and selling financial instruments where the property acquired and disposed of is not an underlying commodity, share, etc. but the derivative contracts themselves. That is to say, profit earned in the context of derivative contracts is not necessarily determined using the same method as is used to compute profit earned from trading actual gold, wheat, or share holdings. Just because a gain in respect of a derivative investment has not be realized in the legal sense, does not mean it has not been "earned" in all substantive respects. For example, it is well known that a taxpayer can "lock" in an "accrued" gain in a derivative market without realizing it in the legal sense. See T.E. McDonnell, "More on GAAP and Profit" (1994) 
Second, the application of s. 9 occurs in two distinct contexts. First, s. 9 requires a reader of the Act to look forward to the detailed business and property income (loss) computation rules with respect to the inclusion into income of certain amounts and the deduction from income of other amounts. However, this s. 9 context occurs only after s. 3 has been considered and the Act has sent the reader to s. 9, with a good business practice profit (loss) being computed in the year for each specific business or property of a taxpayer. Second, s. 9 sends a reader back to s. 3 after the reader has adjusted profit (loss) to reflect each specific income inclusion or expense deductibility provision in the Act that applies to the particular business or property of a taxpayer. Neither context should be divorced from the source of enquiry first established in s. 3 . This two-way context to s. 9 should not be underestimated when one considers the application of specific expense deductibility provisions in the Act. While the principles underlying the deductibility of expenses are not the focus of this article, their relationship to the source of income concept is discussed in notes 103 and 104, section $\mathrm{C}$ of this Part, and again in Part IV, which concerns the convergence of first principles in the case law.

Third, Parliament can and has reversed the effects of the source of income concept. In particular, Parliament enacted s. 20.1 of the Act in 1994, which permits a deduction of interest expense incurred in respect of borrowed money used to acquire capital property (other than real property or depreciable property), or to carry on a business, that is a source before the property is disposed of or the business ceases (i.e., sources to which s. 9(2) and paragraph 3(d) would no longer apply but for s. 20.1).

\section{B. THE TONN DECISION}

The leading decision on applying the "reasonable expectation of profit" rule in the context of the post-1971 statutes is the 1996 Federal Court of Appeal decision in the Tonn case. ${ }^{114}$

\section{The TONN CASE: IsSue, Facts, AND ARguMENTS}

The issue in the Tonn case concerned the appropriateness and application of the "reasonable expectation of profit" rule. The case considered whether and how the rule should be applied to a taxpayer's property for the purpose of determining if a loss was from a property source of income and therefore deductible from income from other sources, as computed under s. 3 of the Act.

The facts of the case are reasonably straightforward. Mr. Tonn purchased a vacant Toronto residential property that contained two rental units for $\$ 245,000$ in August of 1989. The purchase price was financed with a $\$ 50,000$ first mortgage on Mr. Tonn's

42 Can. Tax J. 452 (footnote 9 of that article at 455). Finally, it would be quite extraordinary if the tax law permitted the computation of "profit" enquiry to defer to a subsidiary legal construct used to determine whether revenue has been earned, and which exists for the purpose of determining a best picture business or property source of income profit (loss) in a taxation year. 
principal residence (12.5 percent interest rate), by assuming a $\$ 165,000$ mortgage (11.25 percent interest rate) on the rental property, and by borrowing the remainder (interest free) from the third appellant in the appeal (Mr. Sinanansingh). While a profit was expected by 1992, hoped-for profits did not materialize in 1989-91 — rents were lower than anticipated, and expenses were higher.

The Minister of National Revenue took issue with the losses claimed in 1989-91. The Tax Court judge found that a review of Tonn's books and projections showed that there never was a point in time that a profit could be produced given the level of mortgage interest and taxes payable and dismissed the appeal. Mr. Tonn appealed to the Federal Court of Appeal.

Introduced on appeal by way of affidavit (the presentation of which was objected to by the Crown) were additional details. In particular, that Mr. Tonn discharged the $\$ 50,000$ mortgage on his principal residence in 1991 and, to further lessen the adverse economic situation, was joined in the venture by his wife, and, in 1991, the third appellant converted his mortgage into a one-third equity position. A small profit was the result in 1992.

Counsel for the taxpayers contended that, where a taxpayer's motive is strictly commercial, the Court should refrain from substituting its business judgement unless the taxpayer's expectations are shown to be "patently unreasonable"; further, that the Court should objectively consider the prospects for profits only after a reasonable "start-up" time has been given to a taxpayer to establish a profit; third, that the taxpayers encountered circumstances beyond their control, namely a downturn in the real estate market and a failure in the rental revenues to grow by six percent annually (as projected), which factors were not adequately considered by the Tax Court.

Counsel for the Crown countered by focusing on the reasonableness of the taxpayers' revenue and expense projections. On the expense side, it was noted that certain material expenses were omitted from the projections making those estimates unreasonably low. On the revenue side, it was noted that no explanation was given as to why a six percent revenue growth rate was projected and it was unreasonable. Moreover, the taxpayers took a careless, casual, and unbusinesslike approach, the sum of which reflected no reasonable expectation of profit - thereby precluding Mr. Tonn from deducting the losses for the purpose of computing his "income" for the taxation years.

\section{THE TONN DECISION: COMMENTARY ON THE COURT OF APPEAL} ANALYSIS (LINDEN J.A.; STRAYER AND MCDONALD JJ.A. CONCURRING)

At the Federal Court of Appeal, Linden J.A. embarked on a detailed review and analysis of the nature and background of the "reasonable expectation of profit" rule, after first noting that the jurisprudence is substantial and sometimes confusing, and the case raised difficult factual and legal considerations. 
This jurisprudence appears to have led Linden J.A. to consider the "reasonable expectation of profit" rule from a s. 9(1) "business expense deductibility" perspective. ${ }^{115}$ This approach, however, fails to reflect fully two important nuances in the tax law. Unless these two nuances are brought into focus, the Tonn decision could be referred to in a way that confuses the source of income question addressed by Dickson J. in Moldowan ${ }^{116}$ and by Linden J.A. in Tonn.

First, and subject to comments made in section $\mathrm{C}$ below, the "reasonable expectation of profit" rule is not an expense deductibility test, notwithstanding some confusion in the case law that may trace its origins to the fact that a business or property loss can arise only if expenses exceed revenue from the business or property. Rather, the Moldowan principle concerns the loss (expenses exceed revenue) deductibility issue. This issue is whether a taxpayer's loss from a business or property is deductible under paragraph 3(d) of the Act in computing the taxpayer's total income because the business or property is a source of income to which s. 9(2) and paragraph 3(d) apply. The distinction between the deductibility of business expenses and the deductibility of source losses is crucial to putting in context the "reasonable expectation of profit" rule. The related ss. 3 and 9 interpretative issues are:

- whether a taxpayer's business or property is a source of income; and

- whether s. 9(2) and paragraph 3(d) apply to a taxpayer's loss from a business or property if there is no profit from the business or property to which $s .9(1)$ of the Act has applied (i.e., with the "reasonable expectation of profit" rule shielding taxpayers from the "no profit no source" interpretative approach discussed in Part II).

Second, s. 9(I) is not the starting point in considering a loss deductibility case, notwithstanding that this is the approach generally taken in the case law and by commentators. ${ }^{117}$ Rather, and as indicated above in section A of this Part, the starting point in the analysis is the whole of $s .9$ read in conjunction with s. 3.

Linden J.A. states:

I will set out the legislative provisions applicable to the primary issue in this case, - business expense deductibility.

This s. $[9(1)]$ is the starting point in any analysis of the deductibility of business expenses ...." (Supra note 4: D.T.C. at 6004; C.T.C. at 210 .)

From an expense deductibility perspective, see the comments, supra note 104.

116 Supra note 2.

11 For example, see W.J.A. Mitchell, "Tonn and On and On" in Report of Proceedings of the FortyEighth Tax Conference, supra note 94, 27:1 at 27:2 where Mitchell states:

Business losses arise when expenses exceed revenue, and there has long existed a body of law on the deductibility of expenses. It is suggested that the question should not be whether a loss should be disallowed, ... rather the question should be whether the expenses that made up the loss should be disallowed.... First, one looks to the expenses in the context of s. 9(1) of the Income Tax Act, or, more particularly, in the context of computation of commercial profit. 
Keeping these two nuances in mind, arguably the most important aspect of the Tonn decision is that Linden J.A. found that the "reasonable expectation of profit" Moldowan principle derives its existence from the case law and is an objective rule that applies for the purpose of the Act. ${ }^{118}$ In doing so, contrary views about the existence of the rule expressed by some commentators and judges were rejected. ${ }^{119}$ In particular, Linden J.A. rejects the view that the "reasonable expectation of profit" rule has its genesis, and is confined in the application, to the wording of the definition "personal or living expenses" in the Act. ${ }^{120}$ Moreover, Linden J.A. was careful to connect the "reasonable expectation of profit" rule to the meaning of "source of income" and indicated that the rule establishes a "general limitation on deductibility," ${ }^{121}$ an approach that is consistent with the wording of all of ss. 3 and 9. Further, that the:

Moldowan test may been seen as originating in the principles and purposes of the Act, and viewed as an early harbinger to the modern approach to taxation statutes [which is said to be the teleological (object/purpose) approach and the "words-in-total-context" approach $\left.{ }^{122}\right] .{ }^{123}$

Linden J.A. also determines that the Moldowan principle generally concerns three scenarios. First, situations where the impugned activity has a strong personal element - "the taxpayer is seeking a tax subsidy by deducting the cost of what, in reality, is a personal expenditure." 24 Second, cases where the taxpayer's activity lacks any element of personal benefit and cannot be classified as a hobby, the test is to be applied if a non-business motive is present (e.g., tax shelters or tax avoidance). ${ }^{125}$ Third, the test should be used sparingly in regular commercial situations where no personal element exists and the deductions claimed are not questionable. ${ }^{126}$

The reference to applying the "reasonable expectation of profit" rule sparingly in regular commercial situations was incorrectly taken by some to mean that the "reasonable expectation of profit" rule does not apply in the absence of personal benefit

Supra note 4 (D.T.C. at 6006-9; C.T.C. 214-220).

Supra note 4 (D.T.C. at 6006-9; C.T.C. at 214-20). See also the following articles: S. Silver, "Great Expectations: Are They Reasonable?" (Real Estate Transactions: Tax Planning for the Second Half of the 1990s, Corporate Management Tax Conference, Toronto, June 1995) (Toronto: Canadian Tax Foundation, 1996) 6:1; and R.B. Thomas, "Reasonable Expectation of Profit: Are Revenue Canada's and the Court's Expectations Unreasonable?" (1993) 41 Can. Tax J. 1128.

Supra note 4. Linden J.A. acknowledges the views of Bowman J.T.C.C., R.B. Thomas (ibid.), and S. Silver (ibid.); see D.T.C. at $6007-08$ and C.T.C. at 215.

Supra note 4 (D.T.C. at 6007 ; C.T.C. at 216 ).

The citations of Linden J.A. include Stubart Investments v. M.N.R., [1984] I S.C.R. 536; 84 D.T.C. $6305 ;$ [1984] C.T.C. 294; and Corporation Notre-Dame de Bon-Secours v. Communicaute urbaine de Quebec, [1994] 3 S.C.R. 3; 95 D.T.C. 5017; [1995] I C.T.C. 241.

Supra note 4 (D.T.C. at 6008; C.T.C. at 218) [emphasis added].

Ibid. (D.T.C. at 6010; C.T.C. at 220).

Ibid. (D.T.C. at 6011; C.T.C. at 222). See, for example, the post-Tonn tax-shelter decisions in Walls v. M.N.R., 96 D.T.C. 6142; [1996] 2 C.T.C. 14 (F.C.T.D.) [on appeal] [hereinafter Walls], and Heenan v. M.N.R., 96 D.T.C. 1344; [1995] 2 C.T.C. 2969 (T.C.C.) [on appeal].

Supra note 4 (D.T.C. at $6011-13$; C.T.C. at 223-25). 
or questionable deductions. ${ }^{127}$ These suggestions may have arisen because the "reasonable expectation of profit" rule was described as an expense deductibility test. Nevertheless, consider the following dictum of Linden J.A. in Tonn, concerning the relevant criteria to consider when determining the objective reasonability of a commercial activity: "[R]easonableness is to be assessed on the basis of all the relevant factors, both the already listed ones [in the case law] and any new ones that may be helpful." ${ }^{28}$ That is to say, the relevant factors apply to particular facts on a case-bycase basis with an important factor in purely commercial contexts being: "giving the enterprise a reasonable length of time to prove itself capable of yielding profits." 129

This terminology reflects a source of income concern rather than an expense deductibility issue. What is reasonable will depend on the circumstances including the nature of the enterprise, the scale of the operation, the people involved, and the context

For example, see (A.G.) Canada v. Mastri, 97 D.T.C. 5420; [1997] 3 C.T.C. 234 (F.C.A.), Robertson J.A. with MacGuigan and McDonald JJ.A, concurring [hereinafter Mastri]. Counsel for the Minister adopted the stance that the Tonn decision was wrongly decided in arguing the Mastri case before a different panel of the Federal Court of Appeal. The Tax Court and the litigants took the position the Tonn decision suggested that the "reasonable expectation of profit" rule is applicable only in the context of personal expenses or suspicious circumstances. The Tax Court had found that losses from a commercial activity were deductible despite the fact the taxpayer had no reasonable expectation of profit from the venture.

Robertson J.A. rejected this suggestion and referred the litigants back to the analysis of the Court in the Tonn decision. In particular, Robertson J.A. noted (with respect to references in the Tonn case that the "reasonable expectation of profit" rule be used "sparingly") the following:

It is simply unreasonable to posit that the Court intended to establish a rule of law, to the effect that, even though there was no reasonable expectation of profit, losses are deductible from other income sources unless, for example, the income earning activity involved a personal element. The reference to the Moldowan test being applied "sparingly" is not intended as a rule of law, but as a common-sense guideline for the judges of the Tax Court. In other words, the term "sparingly" was meant to convey the understanding that in cases, for example, where there is no personal element the judge should apply the reasonable expectation of profit test less assiduously that he or she might do if such a factor were present. It is in this sense that the Court in Tonn cautioned against "second guessing" the business decisions of taxpayers. Lest there be any doubt on this point, one need go no further than the analysis pursued by the Court in Tonn. (D.T.C. at 5423; and C.T.C. at 240). Supra note 4 (D.T.C. at 6013; C.T.C. at 226). Linden J.A. referred to the criteria set out in Moldowan (supra note 2; S.C.R. at 486; D.T.C. at 5215; C.T.C. at 313); Landry v. M.N.R., 94 D.T.C. 6624 at 6626; [1995] 2 C.T.C. 3 at 6 (F.C.A.) [hereinafter Landry]; and Sipley v. M.N.R., [1995] 2 C.T.C. 2073 (T.C.C.) at 2075 [hereinafter Sipley].

Supra note 4 (D.T.C. at 6015 ; C.T.C. at 229) [emphasis added]. See also Mohammad v. M.N.R., 97 D.T.C. 5503; [1997] 3 C.T.C. 321 (F.C.A.; Robertson J.A. with MacGuigan and McDonald, JJ.A. concurring). Robertson J.A. indicated in Mohammed that, in the context of a commercial rental operation, the "reasonable expectation of profit" rule has a "start up cost" phase in which a taxpayer must be prepared to show from objective evidence that a profit will materialize within a reasonable period of time (see D.T.C. at 5506-07; C.T.C. at 327-329). Further, that high-ratio financing arrangements make it extremely difficult for a taxpayer to satisfy the rule and interest on such loans is not the type of start up costs contemplated by the Federal Court of Appeal in Tonn (see D.T.C. at 5507; C.T.C. at 329). [In Tonn the principal was paid down very quickly to achieve a profit.] Also, that the "reasonable expectation of profit" rule, which was not an issue in the appeal, applies independently of the requirement that an expense must be reasonable in the circumstances per s. 67 of the Act. 
in which the matter arises. ${ }^{130}$ It should be emphasized that the taxpayers in the Tonn case took steps to reduce the mortgage principal by $\$ 50,000$ in the third year of operation, thereby reducing interest charges which resulted in a small profit in the fourth year of renting the property.

Linden J.A. found that the taxpayers in Tonn were engaged in bona fide commercial activity and the expectation of profit was not unreasonable in the circumstances. ${ }^{131}$ Linden J.A. found that the Tonn case was a matter of an honest error in the taxpayer's judgment, and that losses should not be denied under the "reasonable expectation of profit" rule without first giving the venture a reasonable length of period to prove itself capable of producing profits. ${ }^{132}$

In subsequent cases, the Federal Court of Appeal has further explained how the personal versus commercial aspects of the objective criteria should be applied in particular cases. The follow-up cases include Mastri, ${ }^{133}$ Mohammed, ${ }^{134}$ Watt v. M.N.R. ${ }^{135}$ Morris v. M.N.R., ${ }^{136}$ Humphrey v. M.N.R., ${ }^{137}$ Kuhlmann v. M.N.R., ${ }^{138}$ LaBrèche v. M.N.R., ${ }^{139}$ Carew v. M.N.R., ${ }^{140}$ and Spencer v. M.N.R. ${ }^{141}$ Some of these cases are noted below in section $C$ of this Part for the purpose of considering post-Tonn commentary on the "reasonable expectation of profit" rule. All of these cases are referred to in the Annex to this article for the purpose of summarizing the case law criteria applicable in applying the "reasonable expectation of profit" rule for the purpose of determining the existence of a business or property source of income in loss cases.

Supra note 4 (D.T.C. at 6013-14; C.T.C. at 227).

Ibid. (D.T.C. at 6015; C.T.C. at 229). These circumstances were that unsophisticated taxpayers launched a small rental operation without the aid of sophisticated market analysis at a time when the market looked promising but subsequently, through unforeseen reasons, became perilous. And no personal benefit was being derived from the property (e.g., it was not a vacation property and relatives did not reside in the property).

Supra note 4.

Supra note 127.

Supra note 129.

97 D.T.C. 5459; [1997] 3 C.T.C. 462 (F.C.A.), Décary J.A. with Denault and Robertson JJ.A. concurring [hereinafter Watt].

98 D.T.C. 6639; [1999] I C.T.C. 58 (F.C.A.), Linden J.A. with Desjardins and Létourneau JJ.A. concurring [hereinafter Morris].

98 D.T.C. 6645 (F.C.A.), Marceau J.A. with Létourneau and Robertson JJ.A. concurring [hereinafter Humphrey].

98 D.T.C. 6652; [1999] I C.T.C. 38 (F.C.A.), Décary J.A. with Létourneau J.A. and Chevalier D.J.A. concurring [hereinafter Kuhlmann]. The onus of proof was on the Minister because he altered his position during the appeal to allege no reasonable expectation of profit (the assessment had relied on the "restricted farm loss" rule in s. 31 of the Act).

99 D.T.C. 5083 (F.C.A.), Desjardins J.A. with Pratte and Décary JJ.A. concurring, allowing the taxpayer's appeal from 96 D.T.C. 3217 (T.C.C.) [hereinafter Labréche]. Unfortunately, the Court described the "reasonable expectation of profit" rule as a business expense deductibility test.

99 D.T.C. 5206; [1999] 2 C.T.C. 269 (F.C.A.), Robertson J.A. with Décary and Sexton JJ. concurring; dismissing an appeal from [1994] 2 C.T.C. 2008 (T.C.C.) [hereinafter Carew]. 99 D.T.C. 5267 (F.C.A.), Stone J.A. with Isaac C.J.A. and Desjardins J.A. concurring; dismissing an appeal from [1998] 2 C.T.C. 2758 (T.C.C.) [hereinafter Spencer]. 


\section{POST-Tonn COMMENTARY}

At first, the analysis of Linden J.A. in Tonn was welcomed. For example, Stephen Bowman stated that:

[M]uch is accomplished in the Tonn decision: the cases are substantially reconciled, and the test is established on a jurisdictional foundation that provides an explanation of where it comes from and where it is intended to lead. ${ }^{142}$

Robin MacKnight suggested a "subjective based" direction when he stated:

A refreshing analysis has come from the Federal Court of Appeal potentially limiting the application of the Moldowan tests. Taxpayers can succeed in claiming deductions for losses arising out of cases where the taxpayers' business judgement is imperfect, provided that:

- there is no element of personal use or benefit or "other-than business" motivation for the investment;

- the deductions claimed are not otherwise questionable; and

- the expectation of profit is not subjectively unreasonable based on information available at the time of the investment. ${ }^{143}$

Nevertheless, other post-Tonn commentators criticized the "objective" based direction taken by Linden J.A. in Tonn and the judge-made origin of the objectively-based "reasonable expectation of profit" rule. For example, W.J.A. Mitchell suggests that the finding of Linden J.A. in Tonn, that an objective "reasonable expectation of profit" rule is derived from the case law, is "misguided" 144 and that "[w]hat is needed is a review by the Supreme Court of Canada, where the test can be examined anew and against first principles." 145

Thus, Mitchell implies that the "reasonable expectation of profit" principle may not stand up if examined against original first principles. Mitchell believes that Revenue Canada and the courts should not be "disregarding the subjective test of a taxpayer's purpose and applying instead an analysis not of the taxpayer's purpose but rather of his business wisdom." 146

S.W. Bowman, "The Reasonable Expectation of Profit Test: A New Beginning?" (1996) 44 Can. Tax J. 465 at 469.

R.J. MacKnight, "Prophecies and Soda: Evolving and Surviving Tax Shelters" (Report on the Proceedings of the Forty-Seventh Tax Conference, Toronto, 27-29 November 1995) (Toronto: Canadian Tax Foundation, 1996), 14:1 at 12 [emphasis added].

Supra note 117 at $27: 1$.

lbid. at $27: 5$.

Ibid. at 27:3 [emphasis added]. 
However, Mitchell does not comment on the relevance, if any, of the interrelationship of the loss rule in s. $9(2)$ to the profit rule in s. $9(1)^{147}$ and the source of income concept also in s. 3, nor to the judge-made rules of law arising from the "is the taxpayer's profit from that business or property" terminology. ${ }^{148}$ That terminology replaced the profits received by a taxpayer approach taken in S. 3 of the 1927 Act. Moreover, original first principles included a rule that no longer exists in s. 3 of the Act; namely the taxpayer's "for profit" test in paragraph 3(1)(f) of the 1917 Act. Vestiges of this subjective-intent "for profit test" linger in the definition "personal or living expenses" and the acquisition of corporate control rules that restrict the carryover of certain tax effects (e.g., loss carryovers are restricted by paragraph $88(1.1)(e)$ and s. 111(5)). Mitchell refers instead to the finding of Thorson P. in a case that concerned the income earning purpose rule now found in paragraph 18(1)(a). ${ }^{149}$ As was noted by Linden J.A., however, that rule imposes a subjective standard that a taxpayer must satisfy. ${ }^{150}$ The point is that a taxpayer's subjective income-earning purpose for incurring an expenditure differs from the objective legal question raised by ss. 3 and 9 as to whether a business or property is a business or property source of income in loss cases.

John Owen does relate the "reasonable expectation of profit" rule to the Royal Trust principle, which is an outcome of the "is the taxpayer's profit from that business or property" terminology in s. $9(1) .{ }^{151}$ In particular, a profit computation should respect "ordinary principles of commercial trading and well-accepted principles of business practice." 152 Owen states:

It could be suggested that besides the computation of profit, these principles may be used to determine whether a business exists. In my view, they are to be used only if a business does in fact exist, since

Supra note 117. Mitchell states at $27: 3$ that:

If, as Dickson J. says, "source of income" is equivalent to "business," then the two sentences read together would be "to have a business a taxpayer must have a profit or a reasonable expectation of profit.

However, a profit is produced by a taxpayer's business rather than by the taxpayer to whom the source belongs. Based on the wording, context and object of ss. 3 and 9 detailed in this article, this article articulates the matter differently: a taxpayer's business that produces a profit in a taxation year is a source of income, as is a business that has a reasonable expectation of profit.

See supra note 34.

Supra note 117 at 27:3. The case Mitchell refers to is Imperial Oil v. M.N.R., 47 D.T.C. 1090; [1947] C.T.C. 353 (Ex. Ct.).

In particular, consideration was given by Linden J.A. to the general limitations found in:

- paragraph 18(1)(a), that an expense must be incurred for the purpose of earning income to be deductible, and

- paragraph 18(1)(h), which prohibits the deduction of "personal and living expenses" as defined by s. 248(1) of the Act.

Linden J.A. indicated in Tonn, supra note 4 at 6005 (D.T.C.); at 212 (C.T.C.), that paragraph 18(1)(a) establishes a "subjective" intent to earn income standard that must be met by a taxpayer for the purpose of computing income. However, Linden J.A. notes that the denial of the deductibility rule in paragraph $18(1)(\mathrm{h})$ that is applicable to "personal or living expenses" sets an "objective" test to be met by a taxpayer.

See Owen, supra note 58.

Ibid. at 1004 (Owen relies on the description of Thorson P. in Royal Trust, supra note 33). 
logically it is first necessary to determine whether a business exists before it is appropriate to apply rules aimed at computing the income from that business. ${ }^{153}$

However, Owen limits the application of the rule to distinguishing between a business and a hobby. To Owen, the question is whether the activities of a taxpayer are, objectively, motivated by profit. ${ }^{154}$ Yet, a "for profit" test has not been in s. 3 since paragraph 3(1)(f) of the 1917 Act. To Owen, a business is a source of income, and this conclusion is made without any additional consideration of whether the business has earned a profit to which s. 9(1) has applied. Owen's approach is, it is suggested, incomplete for reasons detailed in section A of this Part.

The focus of Owen's concern appears to be that the "reasonable expectation of profit" rule might be used to deny the deductibility of business expenses (as compared to losses). To Owen, such an approach would involve an "insidious rule that imparts to the courts broad discretion in determining the fate of commercial activities that may be driven at least in part by tax considerations." "iss

Owen maintains that the "reasonable expectation of profit" rule should not be confused with whether incurred expenditures are deductible in relation to a business or property source of income. ${ }^{156}$ Generally, this position appears to be correct subject to three caveats.

First, the business or property must be a source of income. Second, whether a business or property is a source of income should not be confused with whether expenses are deductible because a business or property is a source in a taxation year in which a good-business practice profit is produced in the year, or can reasonably be expected in the year under review. This "good business practice profit" must be independent of a taxpayer's return that is a tax refund or a tax payable reduction generated because some purported source of income helps generate a tax benefit (e.g., a tax refund based on loss offsets to other income). ${ }^{157}$

Ibid., analysis at 1000-15.

See Moloney v. M.N.R., 92 D.T.C. 6570; [1992] C.T.C. 227 (F.C.A.), Hugessen J.A., with MacGuigan and Linden JJ.A. concurring [hereinafter Moloney]. In particular, Hugessen J.A. stated: While it is trite law that a taxpayer may so arrange his business as to attract the least possible tax, it is equally clear in our vicw that reduction of his own tax cannot by itself be a taxpayer's business.... To put the matter another way, for an activity to qualify as a "business" the expenses of which are deductible under paragraph 18(1)(a) [a business that is a source of income], it must not only be one engaged in by the taxpayer with a reasonable expectation of profit, but that profit must be anticipated to flow from the activity itself rather than exclusively from the provisions of the taxing statute. (D.T.C. at 6570 ; and C.T.C. at 227-28.) [footnotes omitted.]

Also see Walls, supra note 125, where the F.C.T.D. considered the above dictum (see 96 D.T.C. at 6146). In Global Communications, supra note 17, the Federal Court of Appeal declined, because of the complexity of the evidence related to revenue generated, to rule on whether the taxpayer's activity, if a business, was carried on with a reasonable expectation of profit independent of an anticipated tax benefit. Rather, the Court indicated that the particular activity was not organized 
Third, non-commercial expenditures, commingled with commercial transactions engaged in by a source, should not be recognized as source of income transactions. Income (loss) calculations apply to expenditures within the ambit of the source only. ${ }^{158}$ This matter is considered again in Part IV as an emerging issue in the case law.

The post-Tonn commentary also criticizes other (post-Tonn) "reasonable expectation of profit" decisions by the Federal Court of Appeal. For example, one commentator stated this about the Mastri ${ }^{159}$ decision:

The legal theory is that a test based on a standard of reasonableness will be capable of equal application to all situations. Once judges are invited to apply a less assiduous test [the reasonable expectation of profit rule] in certain circumstances, can there be any prospect of uniformity? Mr. Justice Robertson invites us to return to the days when the measure of distance known as a foot varied from emperor to emperor depending on the size of his Nikes. ${ }^{1 \mathrm{t}}$

However, Robertson, Linden JJ.A., and other members of the Federal Court of Appeal have stressed in their decisions that all of the facts are relevant in applying the "reasonable expectation of profit" rule. Robertson J.A. does not undermine this position by indicating in Mastri that the "reasonable expectation of profit" rule is a less assiduous test in purely commercial circumstances, thereby endorsing the common sense approach advocated by Linden J.A. (in order not to second-guess business acumen in such cases). ${ }^{161}$ This is because application of the "reasonable expectation of profit" rule is to be made with reference to a particular taxpayer and the particular activity engaged in, rather than being divorced from those factors. ${ }^{162}$

enough to be a business. See 99 D.T.C. at 5384.

See the speech of Jackett, supra note 34. Also see the comments in note 104 and Part IV.

Supra note 127.

D. Wentzell, "The True Meaning of Tonn - Clarification of the Reasonable Expectation of Profit Test" (1997) 45 Can. Tax J. 1359 at 1362 [emphasis added].

Supra note 127 (D.T.C. at 5423; C.T.C. at 241). Also see Wall, supra note 135, in which Décary J. stated: "[w]here a personal element exists, it will prompt the Court to apply the reasonable expectation of profit test more assiduously...." (See D.T.C. at 5460 and C.T.C. at 464).

For example, the Kuhlmann, supra note 138, decision of the Federal Court of Appeal emphasizes that it is the particular nature of the activity that must be assessed: its capitalization, the taxpayer's background and experience, the intended course (plan) and its progress, the risk inherent in the activity and that taking personal satisfaction from the activity can coexist with a profit motive. it should be noted that the litigants in Kuhlmann agreed (mistakenly) that the shift in the onus of proof to the Minister meant that the Minister had to prove that the expectation of profit was "irrational, absurd or ridiculous." In this regard, Judge Bowman of the Tax Court stated the following:

I think that for a business to exist there has to be something more than an absence of irrational, absurd and ridiculous expectations. I do not read the Kuhlmann decision as suggesting otherwise.

I would prefer to read the passage quoted from the Federal Court of Appeal decision as reflecting the possibly hasty adoption of a proposition agreed to by counsel and therefore not thoroughly explored in argument rather than the enunciation of a new principle that in effect overrules over twenty years of jurisprudence. See Rai v. M.N.R., 99 D.T.C. 562 at 564; [1999] Carswell Nat. 193 (T.C.C.) [hereinafter Rai]. 
Moreover, the general tendency in purely commercial circumstances would be that the facts related to a loss from a business or property would be such that the test is satisfied (i.e., that profit is reasonably expected from the particular business or property). Two of the most important factors are the nature of a taxpayer's operation and whether the taxpayer can establish through objective evidence that profit will result given the nature of the enterprise. ${ }^{163}$ The objective evidence not only lends credibility to a purported profit motive but also allows the judiciary to test the reasonableness and credibility of a subjective profit motive without the need to judge a taxpayer to be a liar. Unless a business or property profit expectation satisfies objective criteria, a taxpayer should not be able to claim a subsidy from all taxpayers out of the tax system. This is because the endeavour that produces a loss is not a source of income.

The Federal Court of Appeal has, through its recent decisions on the "reasonable expectation of profit" rule, ensured that the case law adapts and refines the objective criteria applicable on a case-by-case basis to particular facts. This is a reasonable response to the many nuances raised by the direct and indirect reference to the words "business or property," "is the taxpayer's profit from that business or property," "loss," and "source" in the wording of all of s. 9.

\section{Emerging Issue: Convergence of First Principles}

This article has sought to demonstrate that it is the "reasonable expectation of profit" rule only that allows taxpayers to deduct a loss under paragraph $3(\mathrm{~d})$ where the loss is from a business or property that has not had a profit to which paragraph 3(a) and s. $9(1)$ of the Act have applied. This rule can cut for or against a taxpayer, depending on the particular circumstances under consideration.

The principles underlying the deduction of business and property expenses (as opposed to losses) are based upon a subjective-intent focus. Neil Brooks, in 1981, reviewed the principles underlying the deduction of business expenses. ${ }^{164}$ Brooks' review discussed the principles applicable in cases where one moves on from $\mathrm{s} .9$ to the rules mandating statutory adjustments such as those found in ss. 18 and 20. In the context of distinguishing between personal expenses and business expenses for this purpose, Brooks stated:

[T] he distinction between personal and business expenses must be made on the basis of the taxpayer's state of mind when the expense was incurred, ${ }^{\text {ics }}$

and also noted: 
[W] here a legal consequence depends upon a person's state of mind, the courts look at various objective facts from which to draw inferences about the individual's state of mind. ${ }^{160}$

More recently, some have taken the subjective-intent focus of the expense deductibility enquiry to mean that expenses incurred in a taxation year in respect of a business or property that produces gross income (revenue) from the business or property were deductible in the year. For example, see the decision of L'Heureux-Dube $\mathbf{J}$. in Hickman Motors ${ }^{167}$ and of Desjardins J. and LéTourneau J. (in dissent) in Les Enterprises Ludco v. M.N.R. ${ }^{168}$

However, it is the productive nature of an activity or a property that is the essential ingredient to the existence of a source of income $e^{169}$ under paragraph 3(a) and whether any transaction or series of transactions engaged in is within the ambit of the source for the purpose of computing a taxpayer's income (loss) from the source. For example, W.R. Jackett stated at the 1981 Corporate Management Tax Conference the following:

With reference to the possibility of a transaction not falling within the ambit of a business, I merely mention, to illustrate the problem, an authoritative English case [Petrotim Securities v. Ayres, [1964] 1 All E.R. 269 (C.A.)] where a sale otherwise apparently within the scope of the current operations of the vendor's business was held, having regard to the fact that it was a sale at a gross undervalue by one related company to another, to be a device for transferring money from the one company to the other and not to be a sale in the course of the operation of the business. ${ }^{170}$

lbid. at 198.

Supra note 103.

99 D.T.C. 5153 (F.C.A.). The combined decisions of Mr. Justice Marceau (at 5154-59) and Madam Justice Desjardins (at 5159-63) meant that the taxpayer could not deduct interest in respect of shares because the real purpose of the expense was to defer taxes (as determined by a finding of fact at trial). The share investment concerned an offshore tax avoidance arrangement in which taxpayers claimed interest expenses in excess of expected dividends with the tax on accruing capital gains deferred into the future. In dissent, Mr. Justice LéTorourneau found (at 5163-76) that the Minister's approach created uncertainty in the economy and the business community, and that the taxpayers "probably" intended to derive income from the shares. Query: Does this dissent suggest that perceived uncertainty in the business community can overrule the intent of Parliament? For commentary, see K.S.M. Hanly, "Interest on Money Borrowed to Buy Common Shares - What is Your Real Purpose? Dividends or Capital Gains?" (1999) 47 Can. Tax J. 624. Also see F. Barrette, "Interest: Where Are We Now?" (Corporate Management Tax Conference, 1997) (Toronto: Canadian Tax Foundation, 1998) at 8:1.

See section A of Part II of this article ("What is a source of income?").

Supra note 34 at 288 . The Petrotim case concerned a securities company that deliberately sought through a series of transactions to create a loss from the disposition of securities to an associated company for less than fair market value. The taxpayer sought a repayment of tax based upon its trading loss. The English Court of Appeal excluded both the cost of purchase and the revenue obtained from the taxpayer's accounts, because both transactions were done deliberately to obtain a loss rather than in the course of trade. Lord Denning stated at 272 that:

Whoever would suppose that any trader in his right senses would enter into transactions of this kind, that he would sell at a gross undervalue, were it not that he had in mind some benefit out of making a loss?

In Canada, the Exchequer Court applied the Petrotim principle to transactions concerning the cost (acquisition) side of the income computation equation notwithstanding that the transactions concerning the revenue (disposition) side of the income computation equation were within the ambit of the source. See J. Bert Macdonald and Sons Ltd. v. M.N.R., 70 D.T.C. 6032 [hereinafter 
Perhaps it should also be noted that s. 20 of the Act does not bring any particular non-commercial transaction on the expense side of the income computation equation, or non-commercial expenses commingled with commercial transactions entered into by a source, within the ambit of the source of income.

Nevertheless, the Supreme Court of Canada's recent decision in Shell Canada v. $M . N . R{ }^{171}$ suggests that, among other things, the interest expense rule in paragraph $20(1)(c)$ is clear and unambiguous. However, the weak-currency transactions within the borrowing arrangement were non-commercial in the sense that they had no purpose other than to use paragraph $20(1)(c)$ for the purpose of reducing a good business practice profit from Shell's source of income. Yet, it is the Supreme Court of Canada that stated in 1957 in Canada Safeway v. M.N.R. that:

It is important to remember that in the absence of an express statutory allowance, interest payable on capital indebtedness is not deductible as an income expense. ${ }^{172}$

Thus, the Supreme Court in Shell turned the words, the context, and the purpose of paragraph $20(1)(c)$ upside down by permitting Shell to avoid tax on income from Shell's source of income by commingling non-commercial transactions with truly commercial borrowing arrangements entered into in order to satisfy the source's need for financing. Section 3 was not even mentioned by the Court in its decision. Nor did the Court adequately explain how the weak currency portion of the transactions was within the ambit of the business as a source of income, which is required under the law. Section 20 assumes the source exists and does not answer the more fundamental question of whether any particular business or property is productive and therefore is a source of income, or whether any particular expense is within the ambit of the source $^{173}$ for the purpose of computing a taxpayer's income (loss) from the source. Thus, the Supreme Court's analysis appears to leave to another day the implications of s. 3 vis-à-vis non-commercial expenses commingled with a source of income.

In this regard, one should not lose sight of the fundamental nature of the ss. 3 and 9 source enquiry into a taxpayer's productive activity in a given taxation year. Such consideration should be mindful of the historical evolution of the actual words used in ss. 3 and 9, their context and object, and how the judiciary has interpreted the former and current wording. It was not until 1972 that s. 3 included a loss offset rule and a business or property loss rule was incorporated into the then newly enacted s. 9(2), along with an express reference to the business or property as a source of income. It is equally noteworthy that the source reference in the loss rule in s. 9(2) connects back

Macdonald].

(1999) 235 N.R. 384, 171 D.L.R. (4th) 238 (S.C.C.) [hereinafter Shell]. For a critique of Shell, see B.T. Amold, "Supreme Court of Canada Approves Blatant Tax-Avoidance Scheme" (November 1999) 19 Tax Notes International 1813-21.

172 [1957] S.C.R. 717 , 57 D.T.C. 1239 at 1244; [1957] C.T.C. 335 at 344 (S.C.C.). A similar comment was also made by the Supreme Court in 1987 in M.N.R. v. Bronfman Trust, [1987] I S.C.R. 32; 87 D.T.C. 5059 at 5064; [1987] I C.T.C. 117 at 124 (S.C.C.).

173. See the Macdonald and Petrotim cases, supra note 170 , and the comments of Jackett referenced at supra note 34 . 
to the profit from that business or property phrase in s. $9(1)$ and to the source reference in $\mathbf{s .} 3$.

Consider, for example, the relationship of the "reasonable expectation of profit" rule to partnerships and partners, which is an emerging issue in the tax law. ${ }^{174}$ While the outcome of the analysis may depend upon the approach taken by the Supreme Court of Canada to the source of income question, a partnership structure involves at least eight separate and distinct reviews. First, a valid partnership under most partnership statutes requires (a) a business, (b) being carried on in common by two or more persons (c) with the view to profit; and a partnership must be distinguished from its members. ${ }^{175}$ Second, a partner's income from a partnership must be computed by applying the provisions of the Act to the partnership (including the source of income concept in s. 3) as if it were a separate person resident in Canada. See, for example, ss. 96, 3, and 9 of the Act. Third, a partnership is required to compute its income (loss) from each source separately, and these computations concern transactions that are within the ambit of the source.

Fourth, a partner's loss from a business or a property of the partnership (as adjusted by particular provisions of the Act such as s. 20) is deductible against income from another business or property of the partnership only if the particular business or property is a source of income (note: taxable capital gains and allowable capital losses are addressed by subparagraph $96(1)(c)(i))$. Fifth, a member's partnership allocation of an income (loss) from a partnership source of income occurs independently of whether the partnership interest is a source of income at the time of the allocation. See the preamble to s. 96(1) which does not provide that the member must be a partner at the time of the allocation, only that the member be a partner during the member's taxation year. Sixth, the deductibility of a member's share of a partnership's loss from business

See, for example, Spire Freezers v. M.N.R., 99 D.T.C. 5297 (F.C.A.) [hereinafter Spire Freezers], Linden J.A. with Strayer J.A. concurring, Robertson J.A. dissenting. In that case, Robertson J.A. indicates at 5318 that the "reasonable expectation of profit doctrine is intended only to determine whether a business exists." This approach differs from that taken in this article, which takes the position that a business or property (albeit being a business or property) that produces a loss is a business or property source of income only if it has a reasonable expectation of profit. Failure to meet the rule in a current taxation year does not preclude an activity from being a source in a subsequent taxation year in which there is a profit or a reasonable expectation of profit. See Carew, supra note 140 and Sirois, infra note 220. Each taxation year is an independent enquiry into the net income (loss) from each source of income that a taxpayer has in the year. This is the simple answer to Mr. Justice Robertson's concern that future income of the partnership would not be subject to tax if the partnership were determined not to have a source of income in the year under review. It is incorrect to think that future profit would not be included in a partner's income. Obviously, the approach taken in this article differs from that of Mr. Justice Robertson. However, Mr. Justice Robertson's approach appears to be generally consistent with that of John Owen (see analysis in section $\mathrm{C}$ of Part II of this article) and others including Judge Bowman of the Tax Court of Canada (e.g., see Allen v. M.N.R. (12 August 1999) 3096(IT)G (T.C.C.) 4 C.T.C. 199 [hereinafter Continental Bank], per the decision of Bastarache J. (with L'HeureuxDubé J. concurring), which was agreed to by other members of the Supreme Court except that Bastarache $\mathrm{J}$. was wrong to conclude the partnership's business was illegal, as per McLachlin $\mathrm{J}$. (with Gonthier, Cory, lacobucci, and Major JJ. concurring). 
or property is confined to computations in respect of each business or property of the partnership that is a source(s) of income.

Seven, the deductibility of a member's loss is subject to the "at risk" rules for limited partners in ss. 96(2.1) to (2.7). Eight, a member cannot reduce the member's share of partnership income (loss) for the member's taxation year by deducting partner level expenses (e.g., interest expenses in respect of the member's interest) unless the member's partnership interest is a separate source of income at the time the expenses were incurred. ${ }^{176}$ That is to say, the member's partnership interest produced a profit to which s. 9(1) and paragraph 3(a) apply while the interest was held by the member in the taxation year, or a loss if s. 9(1) and paragraph 3(a) might reasonably be expected to apply to the interest.

Finally, Parliament is responsible for addressing any perceived economic or social deficiencies that occur where losses or expenses are not deductible for the purpose of expenses the Act because they were not incurred by a source of income, or within the ambit of a source of income. Parliament has, for example, enacted s. 20.1 of the Act to permit the deduction of interest expenses incurred in respect of certain properties (and businesses) that cease to be sources of income. Other deductible expenses not within the ambit of a source include moving expense in s. 62 and child care expenses in s. 63.

\section{Conclusion}

Whether a business or property that produces a loss in a taxation year is a source of income in the year is a first instance question of law determined by applying the "reasonable expectation of profit" rule. This rule is a key outcome of the flexible language used in the business and property income computation rule in s. 9 of the Act. The "is the taxpayer's profit from that business or property" terminology, and the like, pre-1972 "is the profit therefrom" language, have been used in the business and property income computation rule since the 1948 Act. That terminology replaced the "profits received by a taxpayer" approach taken in the 1927 Act and has spawned case law niches that include the computation of profit cases, capital versus income gain cases, and the "reasonable expectation of profit" cases. In effect, the objective "reasonable expectation of profit" rule arises from the wording and object of all of s. 9 , read in conjunction with the source of income concept also referred to in s. 3 of the Act. This objective rule should not be confused with subjective-intent business "for profit" or "with a reasonable expectation of profit" terminology in the definition "personal or living expenses" in s. 248(1) of the Act and the acquisition of control loss carryover restrictions (e.g., in s. 111(5) of the Act). These two taxpayer-based subjective-intent tests hark back to the initial "for profit" approach taken in $\mathrm{s} .3$ of the 1917 Act, but can apply only to a business or property that is a source of income (as noted above in Part II and Part III, respectively).

176 Ask whether a taxpayer's partnership interest has a profit in the year, or a reasonable expectation of profit. 
The source of income enquiry should also be distinguished from subordinate principles concerning the deductibility of expenses. A convergence of both enquiries is occurring in the case law, as suggested in Part IV above.

Revenue Canada's use of the "reasonable expectation of profit" rule to deny loss deductions has been questioned repeatedly. Nevertheless, the rule evolved to provide a more flexible judicial response to the "no profit no source" approach taken in the case law between 1952 and 1972. The criticisms fail to note that s. 9(2) of the Act, which expressly refers to the $\mathbf{s . 9 ( 1 )}$ source, could be interpreted as applying to a business or property loss only where the business or property earns a profit to which s. 9(1) applies in the particular year, or has earned substantial past profits to which s. 9(1) applied with the business or property having a reasonable expectation of profit in the year under review. As an alternative, the "reasonable expectation of profit" rule permits loss-offsets in respect of a taxpayer's business or property that has yet to produce a profit and therefore favours taxpayers in such cases. Of course, the rule also precludes a taxpayer from deducting losses in respect of a business or property for which there is no reasonable expectation of profit in the circumstances. Thus, the rule can cut for or against a taxpayer depending on the matter at issue and facts in any particular case.

In Part VI below, an annex is provided that provides an articulation of the case law criteria applicable in applying the objective "reasonable expectation of profit" rule.

\section{Annex: an articulation of the Case law Criteria APPLiCable in APPLYiNG the ObJective "Reasonable Expectation of Profit" Rule}

The purpose of this part is to summarize the criteria that the case law states are relevant when applying the objectively based "reasonable expectation of profit" rule to particular facts for the purpose of testing the existence of a business or property as a source of income in a loss case. If there is no actual profit from a business or property in a taxation year, the business or property expectation of profit is central to whether the business or property is a source of income in a loss case. ${ }^{177}$ This source of income question should be distinguished from at least two other matters. First, the source of income question should be distinguished from the subjective-intent business "for profit" or "with a reasonable expectation for profit" terminology in the definition "personal or living expenses" in s. 248(1) of the Act and the acquisition of control loss carryover restrictions (e.g., in s. 111(5) of the Act). These two taxpayer-based, subjective-intent, tests apply to a business or property that is a source of income, and were discussed in detail above in Part II and Part III, respectively. Second, the source of income question should be distinguished from subordinate principles that concern the deductibility of business expenses. The convergence in the case law of the source of income concept and the deductibility of expense cases is discussed in Part IV above. 
The criteria used to determine whether a taxpayer's business or property loss concerns a business or property that has a reasonable expectation of profit and is a source of income are not static nor is each criterion necessarily relevant in any particular fact pattern. The most important factors may vary with the nature and extent of the undertaking (and issue) under review. ${ }^{178}$ Whether a taxpayer's particular business or property that produces a loss has a reasonable expectation of profit and is a "source of income" is a legal conclusion that should be drawn from the facts only after carefully considering all of the facts. Of course, one of those facts is a taxpayer's intent (motive).

It should not be assumed that a taxpayer's activity meets the inclusive definition of "business" as defined by s. 248(1). For example, an activity may be a business or a hobby (e.g., gambling/sporting activity lacking the indicia of a business), and the "reasonable expectation of profit" rule is relevant for the purpose of determining this issue. ${ }^{179}$ In the case of an activity that is a business (or a property held by a taxpayer) that produces a loss, the "reasonable expectation of profit" rule tests the existence of the business or property as a source of income. A non-exhaustive list of matters relevant in this regard include:

1. the taxpayer's background, ${ }^{180}$ experience, ${ }^{181}$ time spent on the activity, ${ }^{182}$ training, ${ }^{183}$ and special skill (e.g., a skilled player of a game or sport $\left.^{184}\right)^{185}$

2. the taxpayer's motivations noting:

A. The existence of a non-commercial motive to the venture raises questions about the expectation of profit, as the legitimacy of the profit expectation from

See M.N.R. v. Matthews, 74 D.T.C. 6193; [1974] C.T.C. 230 (F.C.T.D.) [hereinafter Matthews]. Also see the commentary in note 104 .

See Global Communications, supra note 17 and Rai, supra note 162. In the Rai case, Judge Bowman stated:

Does this activity have sufficient of the indicia of inherent commerciality, revealed in its organization, to make it a business? Would a reasonable person, looking at the activity and applying ordinary standards of commercial common sense, say "yes, this is a business."

(D.T.C. at 563.)

Also see Dubrovsky v. M.N.R., 88 D.T.C. 1712; [1988] 2 C.T.C. 2347 (T.C.C.), which determined that the taxpayer's gambling activities were not a source of income because there was no reasonable expectation of profit; it was a question of luck. For a case in which the necessary skill, etc., existed, see Luprypa v. M.N.R., [1997] 3 C.T.C. 2363 (T.C.C.) [hereinafter Luprypa], which concerned "pool hall" winnings and applies the gambling-income case law. For two cases in which the taxpayers operated sport teams, see Derome v. M.N.R., 93 D.T.C. 25 (T.C.C.) and Nichol v. M.N.R., 93 D.T.C. 1216 (T.C.C.).

See Sipley, supra note 128.

Ibid.

Ibid.

See Luprypa, supra note 179.

Ibid. For a case concerning a race car driver, see Cree v. M.N.R., 78 D.T.C. 1352; [1978] C.T.C. 2472 (T.R.B.).

Also see Moldowan, supra note 2 and Tonn, supra note 4. 
the business or property may be suspect in such cases. ${ }^{186}$ Determine whether a taxpayer is bona fide engaged in a business or whether the purported business or property source is a device to achieve favourable tax effects (e.g., for personal reasons including tax-avoidance); ${ }^{187}$

B. A "profit" from a business or property must exist independently of any tax benefit flowing under the law to a taxpayer because of the activity (e.g., through a reduction of tax payable on income by deducting losses from a purported business source). ${ }^{188}$ That is to say, the "reasonable expectation of profit" from a business or property should stand on its own and not be confused with a taxpayer's motivations and expectations;

C. The absence of a personal element is also a factor to be considered $;{ }^{189}$

D. Where a personal motive is the dominant, motivating force, the taxpayer's burden is considerably more onerous; ${ }^{190}$ and

E. One must give constant and careful attention to the existence of a reasonable expectation of profit in cases where a personal element exists. ${ }^{191}$

However, the reasonable expectation of profit from a business or property can coexist with a personal element such as the taxpayer liking or loving certain aspects of carrying on the business or owning the property. ${ }^{192}$ Conversely, a taxpayer's good faith and reputation and the time and energy expended are not by themselves sufficient to have a business source of income in loss cases. ${ }^{193}$

3. the particular nature of the taxpayer's activity, business, or property ${ }^{194}$

See Tonn, supra note 4; Watt, supra note 135; Humphrey, supra note 137; and Morris, supra note 136.

See Tonn, supra note 4 and Matthews, supra note 178. Also see D'Amico v. M.N.R., [1996] 3 C.T.C. 306 (F.C.A.) [hereinafter $D^{\prime}$ Amico] dismissing an appeal from [1995] 2 C.T.C. 2686 (T.C.C.). D'Amico concerns a tax shelter structure in which investors acquired their interests because of promised losses. There was no reasonable expectation of profit; in the particular case, no profit existed nor was a profit intended.

See Moloney, supra note 157. Also see the analysis of s. 9 of the Act in section A Part IIl of this article, Global Communications, supra note 17, and the comments at note 157 and the commentary in note 104.

See Tonn, supra note 4 and Humphrey, supra note 137.

See Watt, supra note 135.

See Mastri, supra note 127 and Watt, supra note 135. Note that the Minister had the burden in Kuhlmann, supra note 138.

See Watt, supra note 135 and Kuhlmann, supra note 138.

See Landry, supra note 128.

See, for example, Moldowan, supra note 2; Tonn, supra note 4; Dorfman, supra note 76; Mastri, supra note 127; and Landry, supra note 128. Also, Revenue Canada has commented as follows on certain criteria it considers relevant under the "reasonable expectation of profit" rule:

1. Profits and loss experience in past years. Although it may be an indication, the fact that a taxpayer may have incurred continuous losses for several years is not sufficient in and by itself to establish no reasonable expectation of profit. The nature of the activity may require 
including:

A. The intended course of action, ${ }^{195}$ the operational plan and background to the implementation of the plan (including a planned course of action ${ }^{196}$ with sufficient capital or the absence of a business plan or sufficient capital, ${ }^{197}$ or the failure to adjust to changes); ${ }^{198}$

a lengthy start-up period - for example, a tree farm, an artist, a writer.

2. Significance and growth of gross revenue. The most usual indication that an activity does not constitute a business is that it reports no, or a very small amount of, gross income for several years. Conversely, where gross revenue of some significance has been reported or the gross revenue has been increasing year by year, it is an indicator that there is a reasonable expectation of profit.

3. Development of the operation to date. Factors include the amount of capital invested in the operation, the extent to which markets have been developed, or the efforts expended to promote sales.

4. Planned or intended course of action. The taxpayer's planned or intended course of action for developing a profitable operation is considered along with the progress to date.

5. Time spent on the activity in question. The time spent on the activity in comparison to that spent in employment or other income-earning activities is considered. If very little time is spent on the activity in question, there is a presumption that the taxpayer is not carrying on a business unless a substantial amount of the work is contracted out or done by employees.

6. Education, background, and experience. The taxpayer's education, background, and experience is [sic] considered when evaluating the feasibility of the operation to date and the plans for the future.

7. Extent of activity in relation to that of businesses of a comparable size. One of the tests for determining whether or not a particular operation is economically viable is its size. If it is too small to give any hope of profit, the presumption is that it is carried on without a reasonable expectation of profit.

See "Revenue Canada Round Table" (Report of Proceedings of the Thirty-Sixth Tax Conference, Toronto, 26-28 November 1984) (Toronto: Canadian Tax Foundation, 1985) 783 at 834-35. Revenue Canada also commented in 1998 on the impact of recent cases; see R. Couzin \& S.S. Ruby, "The Impact of Recent Cases" [Tonn, supra note 4; Mastri, supra note 127; Mohammad, supra 129; and Kaye, infra note 199] in Report of the Proceedings of the Fiftieth Tax Conference, supra note 107 at 52:3-6.

See Tonn, supra note 4.

16 See Sipley, supra note 128 and Carew, supra note 140.

197 See Landry, supra note 128; Carew, supra note 140; Spencer, supra note 141; and Hugill v. M.N.R., 95 D.T.C. 5311; [1995] 2 C.T.C. 16 (F.C.A.), Robertson J.A. with Stone and McDonald JJ. concurring. In Carew, D.T.C. at 5207, the Federal Court of Appeal stated:

[The] reality is that the taxpayers undertook a venture without sufficient capital and a business plan. The fact that they rented the cabins in question to their relatives is also a factor which cannot be ignored.

In Spencer, the Federal Court of Appeal noted that the Tax Court Judge found that the taxpayer's losses related to travel videos filmed for possible presentation on television, and which were filmed during holidays from full-time commitments at the Department of the Attorney General (Ontario). The Federal Court of Appeal in dismissing the taxpayer's appeal then stated, D.T.C. at 5268, that the Tax Court Judge:

found that these activities were lacking in adequate funding and that no income has been generated since the inception of the concept in 1988 [the taxation years under review were 1992-1994]...;

and that a start-up period "cannot last forever." 
B. The risk inherent in the activity ${ }^{199}$ and the steps taken to manage that risk; $;^{200}$

C. Identifiable source(s) of income (revenue); ${ }^{201}$

D. The capability of the venture as capitalized to show a profit after charging capital cost allowance; ${ }^{202}$

E. The capability of the venture to show a profit after expensing interest from a high ratio mortgage, including whether prompt action is taken to pay the debt down; ${ }^{203}$

F. The reasonable time required to make profitable an activity of the nature under review; ${ }^{204}$

G. The operation's profit and loss experience over past years ${ }^{205}$ and subsequent years; ${ }^{206}$

H. The presence of significant past profits from the business or property; ${ }^{207}$

I. The number of consecutive years during which losses were incurred; ${ }^{208}$

See Kaye v. M.N.R., [1998] 3 C.T.C. 2248 (T.C.C.) [hereinafter Kaye]. In that case, Judge Bowman stated at 2249:

How can it be said that a driller of wildcat oil wells has a reasonable expectation of profit and is therefore conducting a business given the extremely low success rate? Yet no one questions that such companies are carrying on a business. It is the inherent commerciality of the enterprise, revealed in its organization, that makes it a business. Subjective intention to make money, while a factor, is not determinative, although its absence may militate against the assertion that an activity is a business.

One cannot view the reasonableness of the expectation of profit in isolation. One must ask "Would a reasonable person, looking at a particular activity and applying ordinary standards of commercial common sense, say "yes, this is a business"?" In answering this question, the hypothetical reasonable person would look at such things as capitalization, knowledge of the participant, and time spent.

See the reference to wild cat oil well drilling in Kaye, ibid. Also see pool shark gambling in Luprypa, supra note 179, wherein the taxpayer refrained from drinking alcohol during the week and practised regularly to sharpen his ability to shoot pool.

See Spencer, supra note 141 and Rai, supra note 162. In Rai, the source or sources of income were unclear with respect to the taxpayer's horse racing activity for which he claimed expenses. That is to say, whether the source was solely from winnings or whether proceeds from selling horses were to be included. The taxpayer's activity was held to be, among other things, in the nature of a gamble rather than the result of a business enterprise.

See Moldowan, supra note 2.

See Tonn, supra note 4 and Mohammad, supra note 129.

See Tonn, supra note 4 and Landry, supra note 128.

Sce Moldowan, supra note 2.

See Landry, supra note 128.

See Dorfman, supra note 76.

See Landry, supra note 128. 
J. The persistence of the factors causing the losses; ${ }^{209}$

K. Whether the losses were caused by unexpected factors beyond the control of the taxpayer (e.g., a market downturn, loss of key employee, or market-health concern about product); ${ }^{210}$

L. Whether there is present in the venture the ingredients necessary for profits to be earned; ${ }^{211}$

M. Whether there is no possible way that the venture can earn a profit; ${ }^{212}$

N. Whether expenses are increasing as revenues decrease during the course of the relevant years under review (or vice versa); and ${ }^{213}$

O. Whether the potential for future profit has ceased. ${ }^{214}$

However, also see matters 4 and 5 below in this regard.

4. exercise caution with respect to second-guessing business decisions ${ }^{215}$ unless non-commercial motivations exist ${ }^{216}$ or the decisions are so questionable as to put in issue the legitimacy of the expectation of profit. ${ }^{217}$

5. during a start-up period, a taxpayer should be prepared to show through objective evidence the likelihood of a profit materializing from the business or property within a reasonable period of time ${ }^{218}$ or why the losses were caused by factors beyond the taxpayer's control. ${ }^{219}$ Of course, a grace period for

lbid.

See Tonn, supra note 4 and LaBrèche, supra note 139. Also see Kuhlmann, supra note 138, but note the onus was on the Minister (on this point, see the dicta of Judge Bowman in Rai, supra note 162). For a case in which the taxpayer argued unsuccessfully that the losses resulted from identifiable factors that frustrated the orderly development of the initial plan, see Carew, supra note 140. The Tax Court concluded that no business existed until sufficient capital was injected into the venture, which occurred a few years after the losses in question (decision affirmed by the Federal Court of Appeal).

See Landry, supra note 128 and D'Amico, supra note 187.

See Mohammad, supra note 129; Morris, supra note 136; and D'Amico, supra note 187. Also see Landry, supra note 128.

See Landry, supra note 128.

See Brill v. M.N.R., 96 D.T.C 6572; [1997] I C.T.C. 2 (F.C.A.; Linden J.A. with Stone J.A. and Henry D.J. concurring) [hereinafter Brill]. Application of the rule negated certain losses (interest expense based claims) from rental property that had no potential for profit.

See Tonn, supra note 4; LaBrèche, supra note 139; Mastri, supra note 127; and Brill, supra note 214.

See Tonn, supra note 4; Mastri, supra note 127; and Brill, supra note 214.

Sce Landry, supra note 128; Mohammad, supra note 129; and Morris, supra note 136.

See Mohammad, supra note 129.

See Tonn, supra note 4 and LaBrèche, supra note 139. Also sce Kuhlmann, supra note 138 but note the onus was on the Minister (on this point, see the dicta of Judge Bowman in Rai, supra note 162). For a case in which the taxpayer argued unsuccessfully that the losses resulted from 
start-up losses does not apply until an activity becomes a business or property source of income. ${ }^{220}$ The length of the grace period, if any, for a business will depend upon all the facts. Ask whether the business has had a reasonable length of time to prove itself given all the facts including its nature, the scale of the operations, the people involved, and the context.

identifiable factors that frustrated the orderly development of the initial plan, see Carew, supra note 140. The Tax Court concluded that no business existed until sufficient capital was injected into the venture, which occurred a few years after the losses in question (decision affirmed by the Federal Court of Appeal). in a year after a year in which it was found not to be a source, see Sirois v. M.N.R, 88 D.T.C. 1114; [1998] 1 C.T.C. 2147 (T.C.C.) [hereinafter Sirois]. 